OECD Economics Department Working Papers No. 284

Trends in Immigration and Economic Consequences

\section{Jonathan Coppel, Jean-Christophe Dumont,} Ignazio Visco 
Organisation de Coopération et de Développement Economiques

Organisation for Economic Co-operation and Development

18-Jun-2001

ECONOMICS DEPARTMENT

English text only

Cancels \& replaces the same document of 01 February 2001

TRENDS IN IMMIGRATION AND ECONOMIC CONSEQUENCES

ECONOMICS DEPARTMENT WORKING PAPERS No. 284

by

Jonathan Coppel, Jean-Christophe Dumont and Ignazio Visco

Most Economics Department Working Papers beginning with No. 144 are now available through OECD's Internet Web site at http://www.oecd.org/eco/eco/ 


\section{ABSTRACT/RÉSUMÉ}

This paper reviews immigration trends and their economic impacts in a number of OECD countries. While migration systems present similarities across countries, institutional arrangements vary widely and impact on the size and composition of migration flows. Some of the main factors driving immigration are then briefly discussed. The paper also considers the economic, fiscal and social implications of immigration. The study suggests that immigration can confer small net gains to the host country. However, the benefits are not necessarily evenly distributed and some groups, in particular those whose labour is substitutable with immigrants may lose, calling for a smooth working of labour and product markets in OECD countries. The paper also claims that, while migration can partly offset slower growing or declining OECD populations, it cannot provide by itself a solution to the budgetary implications of ageing populations. Finally, the paper touches on some development issues, such as the potential gains from emigration in source countries and the role host countries can play in reducing immigration pressures through more open markets and greater transfers of technology.

\section{JEL Code: F22, J61}

Keywords: Migration, ageing, labour markets, development

$$
* * * *
$$

Cette étude examine les tendances de l'immigration et leurs consequences économiques dans un certain nombre de pays de l'OCDE. Si les systèmes d'immigration présentent des similitudes dans la plupart les pays, les arrangements institutionnels varient énormément et ont une incidence sur la taille et la composition des flux migratoires. Quelques uns des principaux facteurs expliquant les flux migratoires sont ensuites brièvement passés en revue. L'article considère aussi certaines des implications économiques, budgétaires et sociales de l'immigration. L'immigration peut conférer de légers gains nets au pays hôte. Cependant, les bénéfices ne sont pas nécessairement distribués de manière égale et certains groupes, en particulier ceux dont le travail est substituable à celui des immigrés, peuvent s'avérer perdants. Cela confirme la nécéssité pour les pays de l'OCDE d'avoir des marchés des biens et des produits qui soient les plus souples possible. L'étude indique aussi que, si les flux migratoires peuvent partiellement compenser le ralentissement de la croissance ou le déclin des populations dans l'OCDE, ils ne peuvent en aucun cas fournir une solution aux problèmes budgétaires liés au vieillissement des populations. Enfin, l'article discute de quelques problèmes de développement, tels que les gains potentiels à attendre de l'émigration pour les pays d'origine et le rôle que peuvent jouer les pays d'accueil pour réduire les pressions migratoires à travers l'ouverture des marchés et les transferts de technologie.

Classification JEL : F22, J61

Mots-clés : émigration, viellissements des populations, marché du travail, développement

Copyright OECD, 2001

Applications for permission to reproduce or translate all, or part of, this material should be made to: Heads of Publications Service, OECD, 2 rue André Pascal, 75775 Paris Cedex 16, France. 
TABLE OF CONTENTS

TRENDS IN IMMIGRATION AND ECONOMIC CONSEQUENCES …….........................................

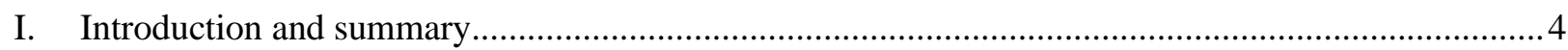

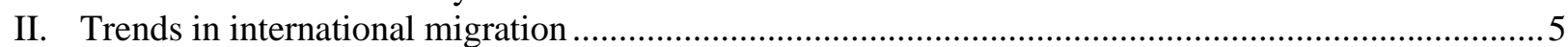

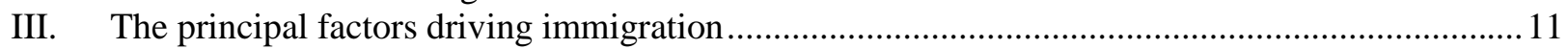

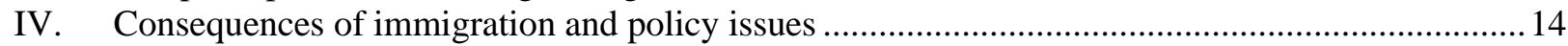

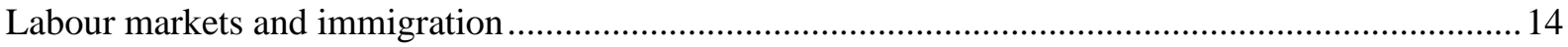

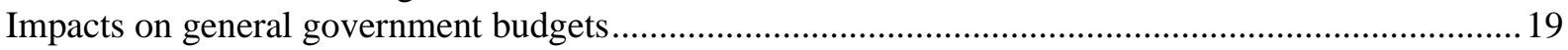

Is increased immigration a solution to ageing OECD populations? ....................................................20

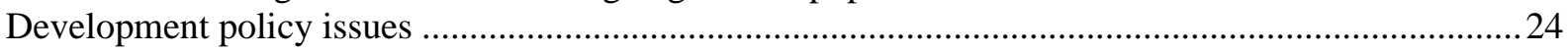

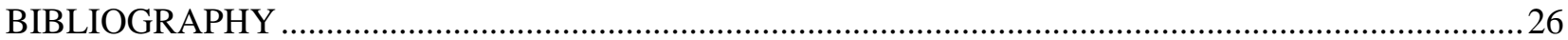

Tables

1. Main immigrant countries of origin in selected OECD countries in 1997-98

2. $\quad$ Foreign of foreign born population in selected OECD countries

3. Foreign and national adult population classified by level of education in selected OECD countries

4. Employment of foreigners and nationals by industry division

5. Per capita income in source relative to host countries in current PPP \$, 1997

6. Disparities between disadvantaged areas and the urban average in selected OECD

7. Immigration by eligibility category in selected OECD countries

8. Share of foreign births in total births relative to the share of foreigners in the total population in selected OECD countries, 1980 and 1988

9. Worker remittances in selected emigration countries, 1998

\section{Figures}

1. Arrivals of foreigners into OECD countries in 1998

2. Net migration in major OECD areas

3. Immigration and unemployment rates in OECD countries

4. Foreign-born and native unemployment rates

5. $\quad$ Foreign and national population by age group

6. Immigration and ageing 


\title{
TRENDS IN IMMIGRATION AND ECONOMIC CONSEQUENCES
}

\author{
Jonathan Coppel, Jean-Christophe Dumont and Ignazio Visco ${ }^{1}$
}

\section{Introduction and summary}

1. For a variety of reasons, international migration has long been a concern in both originating and receiving countries. Recently, the debate has focussed on the role that immigration may play in easing the economic and budgetary impacts of declining and ageing OECD populations and addressing skilled labour shortages in sectors such as information technology. This paper reviews recent trends in international migration and then attempts to synthesise what is known about the impacts of immigration on four themes linked to migration in OECD countries. These themes are: $i$ ) what are the consequences of immigration for labour market performance? And what role can immigration play easing skilled labour shortages in specific sectors? ii) what are the budgetary impacts of immigration? iii) to what extent is immigration a solution to ageing and declining OECD populations? and $i v$ ) what are the consequences of migration on economic development in the source country? The main findings can be summarised as follows:

- Most studies suggest that immigration confers small net gains in terms of per capita output to the host country, but the distribution of the benefits is not necessarily even and depends on the qualification structure of the immigrant and native-born workforce.

- Past immigration has had no obvious impact on native unemployment. It might even have been beneficial for the economy and for native employment to the extent that it acts as a source of flexibility.

- A number of OECD countries have recently moved to favour the immigration of more skilled labour. It is difficult, however, to closely influence the level and composition of net migration. Policies that favour targeted skilled migration have also raised concerns of a possible "brain drain" in less developed countries.

- Immigration impacts on government expenditures and revenues, but the net impact at the national level seems to have been negligible so far.

- Increased immigration can limit the adverse impact on living standards and government budgetary positions due to declining and ageing populations, but cannot on its own resolve the problem.

- Policies to stimulate economic development may reduce the incentive to emigrate from developing countries.

1. Jonathan Coppel and Ignazio Visco are from the Economics Department and Jean-Christophe Dumont is from the Directorate for Education, Employment, Labour and Social Affairs. The authors would like to thank Martine Durand, Jorgen Elmeskov, Mike Feiner, Jean-Pierre Garson, Philip Hemmings and Peter Jarrett for comments and suggestions on previous versions of the paper. We also thank Debra Bloch and Cecile Thoreau for technical support and Susan Gascard for secretarial assistance. Views are ours and do not necessarily reflect those of the OECD or its Member countries. Some of the material contained in this paper has been anticipated in Visco (2000b) and OECD (2000a). 


\section{Trends in international migration}

2. Since available data is largely determined by the migration systems that countries have put in place, it is important to first review the main features of OECD country migration frameworks. These have historically developed alongside the evolution of nation-states and the concomitant desire to enumerate and sometimes influence the size and composition of the native population. As such, migration policies have been shaped by domestic considerations and consequently no two systems are alike. Nonetheless, it is possible to distinguish five features shared across OECD countries. These are: acceptance of foreigners to visit for a short period of time for business or tourism purposes (sometimes requiring a visa); rules which allow spouses and close relatives of citizens to enter the country on a permanent basis (family reunion); the possibility for individuals who claim social and political persecution in their country to apply for asylum (asylum seekers); mechanisms for individuals to enter largely for the purpose of employment and business ("skill-based" migration) and naturalisation rules which enable foreign citizens to acquire national citizenship. It is also convenient to distinguish between "temporary" permit systems, common in European countries, Japan and Korea and "permanent" resident or settlement systems as in Australia, Canada, New Zealand and the United States. ${ }^{2}$ While there are common features found in all OECD countries' immigration policies, the institutional arrangements used for their application and the relative importance of their features vary widely. In European countries most entrants arrive via family reunification or as asylum seekers, with different government bodies charged with administering requests for family reunion, asylum and "skill-based" migration. ${ }^{3}$ In contrast, settlement systems are typically based on specific selection criteria and usually managed through a single government agency, which typically provides a more holistic -- and perhaps transparent -- policy.

3. Given the nature of the main data sources, a number of statistical caveats should be borne in mind when assessing the overall scale of immigration, the number of foreign residents and some of their key characteristics (see Box 1). Caution is especially required when interpreting flows and stocks of immigrants across countries. Furthermore, the analysis presented here deals primarily with legal immigration, although illegal migration is thought to account for a significant proportion of migration flows (see below).

4. Bearing the statistical caveats in mind, the size and pattern of immigration has changed markedly in recent decades and varies widely among OECD countries:

- The United States has historically been, and continues to be, an important net recipient of immigrants and is the largest gross recipient of immigrants in absolute terms among the OECD countries (Figure 1, top panel). ${ }^{4}$ Relative to population, however, gross immigration rates are now about half the rate recorded between the middle of the $19^{\text {th }}$ century and the first two decades of the $20^{\text {th }}$ century.

2. For a more detailed classification, see OECD, 1994 edition of Trends in International Migration and Garson and Thoreau (1999).

3. Although European countries are often characterised as having temporary migration systems, immigrants often remain in the host country indefinitely or for long periods of time.

4. The sources for net migration and gross migration flows are different. The former is based on population registers, with net migration calculated as a residual and the latter is based on administrative formalities. The two series are not directly comparable. 
In OECD countries the principal sources of migration data are population registers, residence or work permits, censuses and, in a few cases, dedicated surveys. These sources generally do not have as their raison d'être the recording of migration, and this makes it difficult to compile harmonised and comparable data. Moreover, they only provide official information based on legal entry and do not capture clandestine migration flows. Problems associated with the actual timing of migrant arrivals or departures and breaks in time series are common, since often the data are based on administrative formalities, which change frequently and do not apply to everyone. For example, in cases where data are based on the issuance of permits, arrivals data may not correspond with actual movements, since individuals may decide not to use the permit or to delay arrival. In other cases, illegal immigrants may already be in the country, but only counted when their status changes. ${ }^{1}$ A particular problem is identifying the level of intra European Union migration flows, since there are no restrictions on movement and reporting requirements are difficult to enforce. Changes in status and governmental procedures can, therefore, lead to substantial, and in some sense artificial variation over time in the recorded arrivals.

International comparisons, notwithstanding great efforts by the United Nations to collect data based on a common approach (United Nations, 1998), are even more difficult, given the diversity of sources, lack of common definitions and the different compilation methods used. In particular, some OECD countries define the immigrant population as those of foreign nationality (European countries, Japan and Korea), whereas others count the number of foreign-born persons (Australia, Canada, New Zealand and the United States). In the former case, the stock of migrants in the overall population tends to be lower because naturalised citizens are not considered to be immigrants. This, however, is not always the case, as some countries have nationality laws which limit the scope for foreigners, even for their children who are born in the host country, to become naturalised citizens. ${ }^{2}$

1. In the United States, for instance, at least half the number of immigrants issued with a permanent residence permit in 1986 and 1995 were already in the country when their status was adjusted following amnesty programmes.

2. For a more detailed discussion on migration statistics, see the statistical annex in OECD, Trends in International Migration.

- Most European countries have switched away from being emigration nations and, as a result, in most years over the past four decades the European Union (EU) as a whole has been receiving a net inflow of migrants (Figure 2). Net flows rose through the 1980s and peaked in the early 1990s, driven by the fall of the "iron curtain" and a number of wars and ethnic conflicts, which led to an increased volume of asylum seekers, especially in Germany, the Netherlands, the Nordic countries and the United Kingdom. Since then tighter controls on immigration have led to a decline in legal arrivals. ${ }^{5}$

- In Japan, net migration has traditionally been negligible. Recently, however, restrictions on temporary migration have been eased and in 1998 Japan received approximately 270,000 arrivals. But, relative to population, arrivals remain limited, compared with a number of the smaller OECD countries (Figure 1, lower panel).

5. Arrivals of migrants can mask the underlying scale of inward and outward movements in some countries because of the relative importance of emigration. Germany, for instance, receives about four times as many arrivals as most other European countries where data are available and yet the net intake of migrants is similar to other major host countries in Europe. 
Figure 1. Arrivals of foreigners into OECD countries in 1998
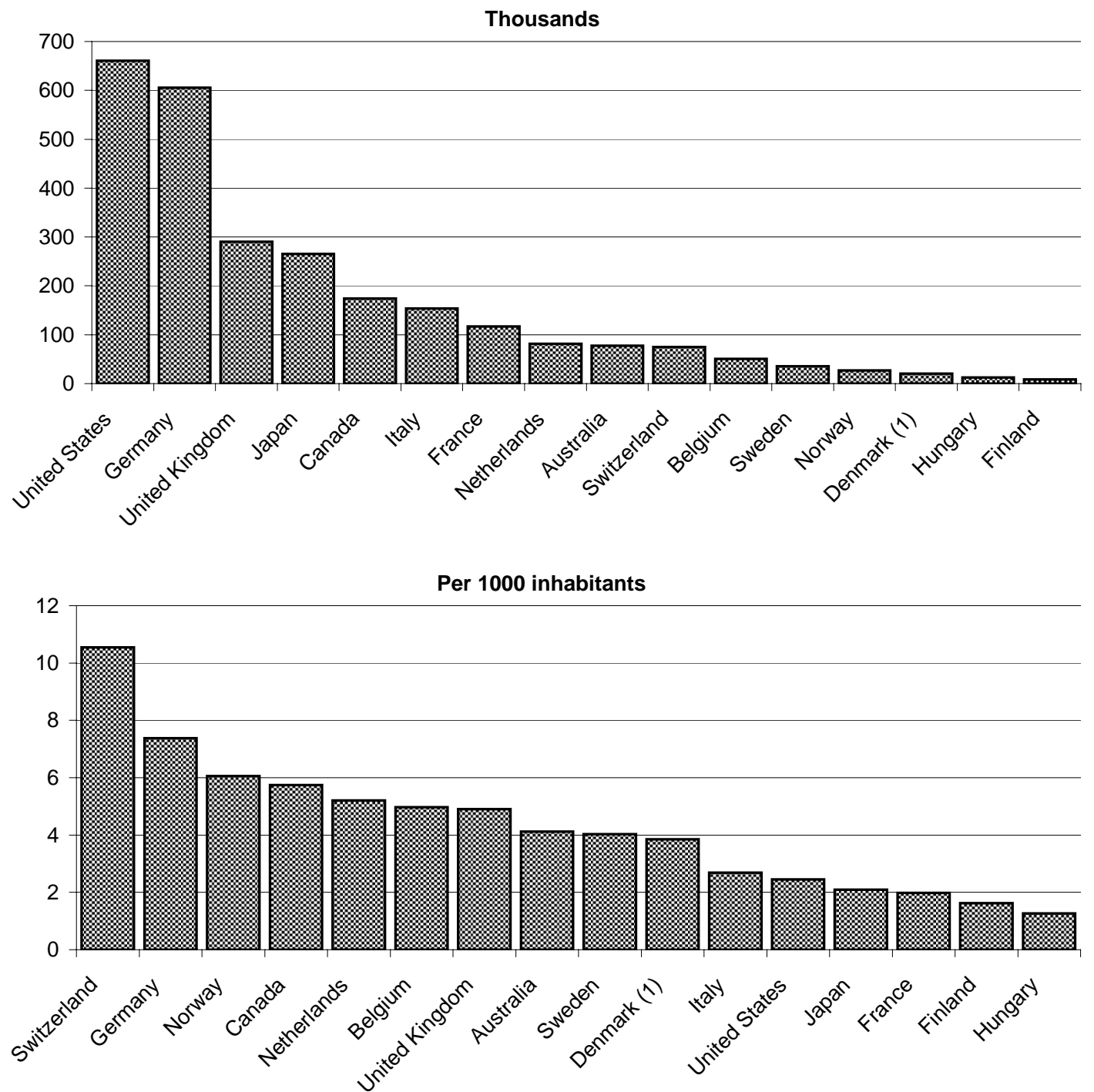

1. Data for Denmark refer to 1997.

Source: OECD International Migration Database; ISTAT (1998), Rapporto Annuale. 


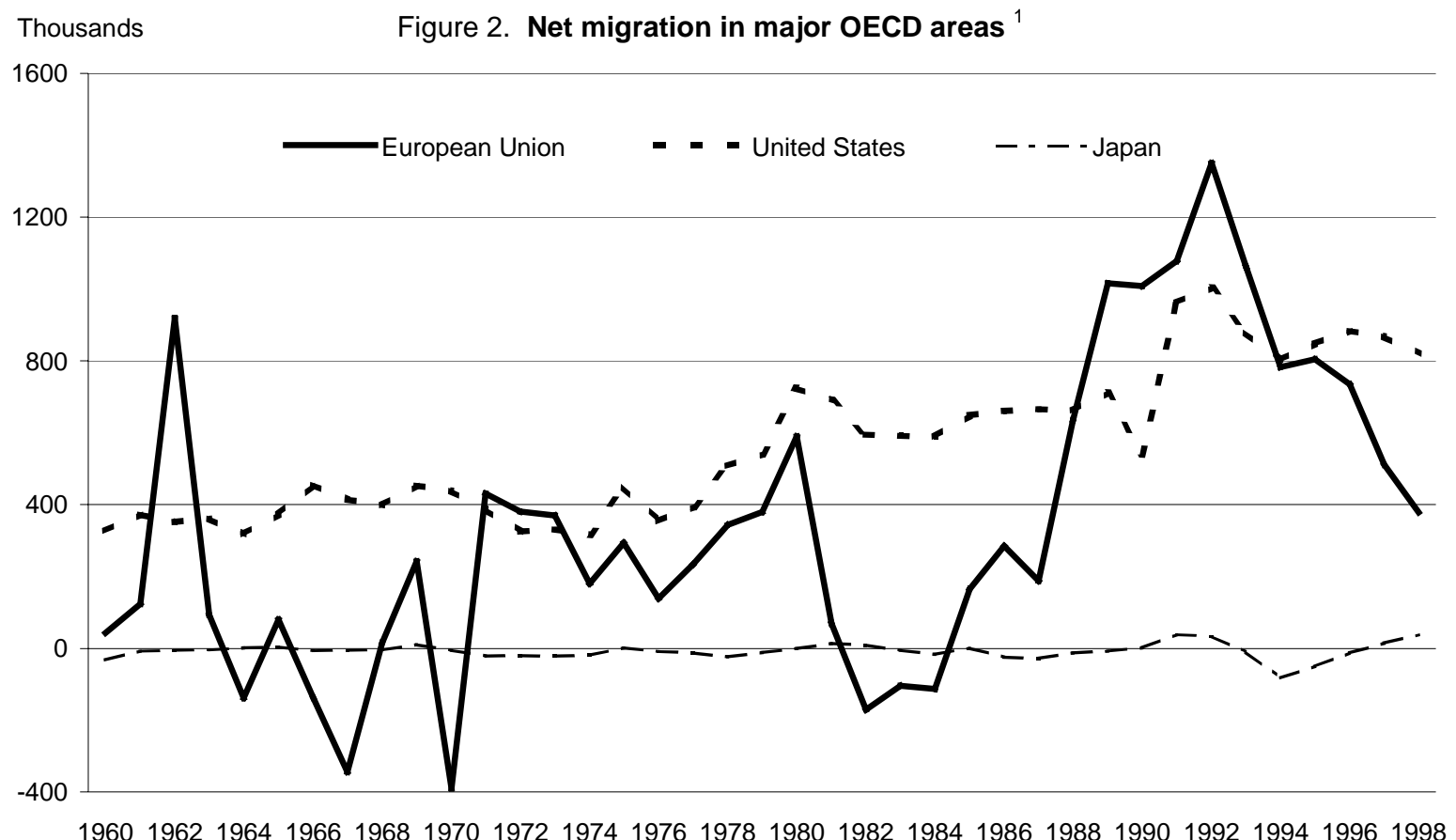

1. Net migration is measured as the difference between the total population on 1 January and 31 December for a given calendar year, minus the difference between births and deaths.

Source: OECD Labour Force Statistics; Eurostat (1999), Demographic Statistics.

5. The number of source countries for migrant arrivals have increased in almost all OECD countries and their distribution differs considerably among countries. For example, the largest groups of foreigners to arrive in Germany are of Turkish and East European origin. In Italy, the recent rise in inward flows is mainly of Albanian, ex-Yugoslav and North African origin, and for France and the United Kingdom people from former territories and colonies remain an important source of arrivals. In the United States, the main group of new immigrants come from Mexico, whereas in Australia they predominantly come from Asian countries, New Zealand and the United Kingdom. Cross-country differences in source countries, therefore, still largely reflect geographical proximity and historical ties. Nevertheless, in many countries the composition of immigrants by nationality of origin has changed compared with past migration patterns. Chinese immigrants, for instance, now rank among the five main nationalities of immigrants in a number of OECD countries, although they still represent only a small share of the overall number of foreigners (Table 1).

6. In nearly all OECD countries the majority of new arrivals are linked to family reunification. This is notably the case in the United States and France, with family reunification accounting for some $3 / 4$ of the overall number of new arrivals. Over the past decade, however, the volume of asylum seekers has increased in many OECD countries, and in 1998 accounted for between 5 per cent of arrivals in the Slovak Republic and just over 40 per cent in Sweden. The third main category of immigrant are those that come primarily to work. 
Table 1. Main immigrant countries of origin in selected OECD countries in 1997-98

\begin{tabular}{|c|c|c|c|c|c|}
\hline & $\begin{array}{l}\text { Inflows of foreigners by } \\
\text { country of origin as \% of } \\
\text { total }^{1}\end{array}$ & $\begin{array}{l}\text { Stock of foreigners by } \\
\text { country of origin as } \% \text { of } \\
\text { total }^{2}\end{array}$ & & $\begin{array}{c}\text { Inflows of foreigners by } \\
\text { country of origin as } \% \text { of } \\
\text { total }^{a}\end{array}$ & $\begin{array}{l}\text { Stock of foreigners by } \\
\text { country of origin as \% of } \\
\text { total }^{b}\end{array}$ \\
\hline Australia $^{c}$ & & & Germany & & \\
\hline New Zealand & 22.2 & 7.5 & Poland & 10.9 & 3.8 \\
\hline United Kingdom & 10.4 & 27.4 & Fed. Rep. of Yugoslavia & 10.2 & 9.8 \\
\hline China & 7.3 & 2.8 & Turkey & 8.0 & 28.6 \\
\hline South Africa & 6.0 & 1.4 & Italy & 5.9 & 8.3 \\
\hline Philippines & 3.9 & 2.4 & Russian Federation & 4.7 & 2.3 \\
\hline Belgium & & & Japan & & \\
\hline France & 14.6 & 11.5 & China & 21.0 & 17.0 \\
\hline Netherlands & 12.3 & 9.1 & Philippines & 17.9 & 6.3 \\
\hline Morocco & 8.5 & 14.7 & United States & 10.4 & 2.9 \\
\hline Germany & 6.3 & 3.7 & Brazil & 8.3 & 15.7 \\
\hline United States & 5.6 & 1.4 & Korea & 6.4 & 43.5 \\
\hline Canadac & & & Netherlands & & \\
\hline China & 11.3 & 4.6 & Morocco & 6.5 & 20.0 \\
\hline India & 8.8 & 4.7 & Turkey & 6.3 & 16.9 \\
\hline Philippines & 4.7 & 3.7 & Germany & 5.8 & 7.9 \\
\hline Hong Kong (China) & 4.6 & 4.8 & United Kingdom & 5.8 & 5.8 \\
\hline Pakistan & 4.6 & .. & United States & 4.0 & 1.9 \\
\hline Denmark & & & Norway & & \\
\hline Somalia & 8.6 & 4.1 & Sweden & 22.4 & 11.0 \\
\hline Former Yugoslavia & 7.1 & 13.5 & Denmark & 8.0 & 11.5 \\
\hline Iraq & 6.3 & 3.4 & United Kingdom & 4.7 & 6.9 \\
\hline Germany & 5.5 & 4.8 & Germany & 4.0 & 3.2 \\
\hline Norway & 5.3 & 4.8 & Somalia & 4.0 & .. \\
\hline Finland & & & Sweden & & \\
\hline Former USSR & 29.8 & 23.6 & Iraq & 15.1 & 4.5 \\
\hline Sweden & 9.6 & 9.3 & Finland & 8.4 & 18.4 \\
\hline Estonia & 8.1 & 12.0 & Former Yugoslavia & 5.4 & 6.1 \\
\hline Somalia & 4.3 & 6.5 & Norway & 4.6 & 5.6 \\
\hline Iraq & 3.2 & 3.0 & Iran & 4.1 & 4.8 \\
\hline France & & & United Statesc & & \\
\hline Algeria & 14.3 & 16.4 & Mexico & 19.9 & 21.7 \\
\hline Morocco & 13.8 & 16.9 & China & 5.6 & 2.7 \\
\hline Turkey & 5.8 & 5.2 & India & 5.5 & 2.3 \\
\hline China & 4.9 & 0.3 & Philippines & 5.2 & 4.6 \\
\hline Tunisia & 4.6 & 6.3 & Dominican Republic & 3.1 & 1.8 \\
\hline
\end{tabular}

a) Data refer to 1998, except for Australia (1999) and Denmark (1996).

b) Data refer to 1997. For Australia, Canada and Denmark data refer to 1996.

c) Stocks of foreign-born population for Australia, Canada and the United States.

Source: OECD.

7. Reflecting the increase in immigration during the 1980s and early 1990s, the stock of the foreign population in the OECD area (where data are available) rose by over 13 million between 1988 and 1998, to reach nearly 57 million persons, equivalent to 7 per cent of the total population. In Europe, the proportion is relatively low at about 5 per cent in 1998, compared with around 20 per cent in Australia and Canada and nearly 10 per cent in the United States. However, within Europe the size of the foreign relative to the overall population spans a wide range (Table 2).

8. The characteristics of the foreign population differ in some important respects from the national profile. In a number of large OECD countries, almost half the foreign adult population only has a lower secondary level of education (Table 3). This, in part, reflects past demands for low-skilled workers in the manufacturing sector, notably in many European and "settlement" countries, such as Australia and Canada where the share of foreigners employed in industry is larger than the corresponding share for nationals (Table 4). In the United States, the share of foreigners employed in agriculture is also disproportionate compared with the share for nationals. The dichotomy in educational attainment levels between the native and foreign populations is likely to narrow, if the increasing emphasis on inflows of skilled workers continues (see below). 
9. As noted earlier, both gross arrivals and net flows of immigrants may underestimate the level of migration due to the movements of illegal or clandestine immigrants. These are immigrants who enter unlawfully, overstay the expiration date of their visa or asylum seekers who remain despite not having been granted political refugee status. By definition it is impossible to know exactly how many illegal immigrants enter OECD countries, but they may be more significant now as compared with earlier periods. Efforts have been made to estimate the importance of illegal immigration based on the response to "regularisation" programmes. In the United States, a relatively recent estimate suggested that the number of illegal immigrants entering in 1996 was approximately 300 000, equivalent to one third of the number of legal immigrants that year (Warren, 1997). In Europe, estimates of clandestine immigration by the International Centre for Migration Policy Development have been put as high as half a million a year, implying an even larger proportion of illegal to legal immigrants. For Japan, the number of undocumented residents was officially estimated at the beginning of 1999 at 270 000. And in Australia, the number of temporary visitors who fail to return on the expiry of their visa was estimated at about 53000 persons in mid-1999 (DIMA, 1999). Moreover, within-year gross flows of clandestine migrants are believed to be even higher, suggesting that many must enter and leave again after a short period of time.

Table 2. Foreign or foreign born population in selected OECD countries

\begin{tabular}{|c|c|c|c|c|}
\hline & \multicolumn{2}{|c|}{ Thousands } & \multicolumn{2}{|c|}{ Per cent of total population } \\
\hline & $1988^{b}$ & $1998^{c}$ & $1988^{b}$ & $1998^{c}$ \\
\hline Australia $^{a}$ & 3753 & 3908 & 22.3 & 21.1 \\
\hline Austria & 344 & 737 & 4.5 & 9.1 \\
\hline Belgium & 869 & 892 & 8.8 & 8.7 \\
\hline Canada $^{a}$ & 4343 & 4971 & 16.1 & 17.4 \\
\hline Denmark & 142 & 256 & 2.8 & 4.8 \\
\hline Finland & 19 & 85 & 0.4 & 1.6 \\
\hline France & 3714 & 3597 & 6.8 & 6.3 \\
\hline Germany & 4489 & 7320 & 7.3 & 8.9 \\
\hline Ireland & 82 & 111 & 2.4 & 3.0 \\
\hline Italy & 645 & 1250 & 1.1 & 2.1 \\
\hline Japan & 941 & 1512 & 0.8 & 1.2 \\
\hline Netherlands & 624 & 662 & 4.2 & 4.4 \\
\hline Norway & 136 & 165 & 3.2 & 3.7 \\
\hline Portugal & 95 & 178 & 1.0 & 1.8 \\
\hline Spain & 360 & 720 & 0.9 & 1.5 \\
\hline Sweden & 421 & 500 & 5.0 & 5.6 \\
\hline Switzerland & 1007 & 1348 & 15.2 & 19.0 \\
\hline United Kingdom & 1821 & 2207 & 3.2 & 3.8 \\
\hline United States $^{a}$ & 19767 & 26300 & 7.9 & 9.8 \\
\hline Total $^{d}$ & 43571 & 56719 & 5.7 & 6.9 \\
\hline \multicolumn{5}{|c|}{ a) Data for the United States, Canada and Australia refer to foreign-born population. See } \\
\hline \multicolumn{5}{|c|}{ b) 1990 for the United States; 1991 for Canada and Australia; 1982 for France. } \\
\hline \multicolumn{5}{|c|}{ c) 1990 for France; 1996 for Canada and Australia. } \\
\hline \multicolumn{5}{|l|}{$\begin{array}{l}\text { d) For those countrie } \\
\text { above footnotes. }\end{array}$} \\
\hline \multicolumn{5}{|c|}{ Source: OECD International Migration Database; OECD Labour Force Statistics. } \\
\hline
\end{tabular}


Table 3. Foreign and national adult populations classified by level of education in selected OECD countries ${ }^{a}$

\begin{tabular}{|c|c|c|c|c|c|c|}
\hline & \multicolumn{6}{|c|}{$1995-98$ average, percentages } \\
\hline & \multicolumn{2}{|c|}{ Lower secondary } & \multicolumn{2}{|c|}{ Upper secondary } & \multicolumn{2}{|c|}{ Third level } \\
\hline & Foreigners & Nationals & Foreigners & Nationals & Foreigners & Nationals \\
\hline United States $^{b}$ & 35.0 & 15.7 & 24.1 & 35.0 & 40.9 & 49.3 \\
\hline Germany & 48.5 & 13.2 & 37.0 & 62.2 & 14.4 & 24.6 \\
\hline France & 63.3 & 33.4 & 22.9 & 45.4 & 13.8 & 21.1 \\
\hline Italy & 47.1 & 56.3 & 38.3 & 34.3 & 14.6 & 9.3 \\
\hline United Kingdom & 65.1 & 43.9 & 14.7 & 32.5 & 20.2 & 23.7 \\
\hline Canada $^{c}$ & 22.2 & 23.1 & 54.9 & 60.3 & 22.9 & 16.6 \\
\hline Sweden & 30.8 & 20.4 & 41.5 & 50.3 & 27.7 & 29.3 \\
\hline \multicolumn{7}{|c|}{$\begin{array}{l}\text { a) The educational attainment classification is defined as follows: lower secondary refers to pre-primary } \\
\text { education or none, primary or lower secondary; upper secondary refers to upper secondary education } \\
\text { or post-secondary non tertiary education; third level refers to tertiary education. }\end{array}$} \\
\hline \multicolumn{7}{|c|}{$\begin{array}{l}\text { b) Foreign-born and native populations aged } 25 \text { and over. Lower secondary refers to less than high schoo } \\
\text { diploma, upper secondary refers to high school diploma, and third level refers to some college or more. } \\
\text { c) Foreign-born and native populations aged } 25 \text { to } 44 \text {. Lower secondary refers to below grade } 9 \text {, upper } \\
\text { secondary refers to grades } 9 \text { to } 13 \text {, and third level refers to some post-secondary education plus } \\
\text { university degrees. }\end{array}$} \\
\hline Sources: Labour F & Surveys (E & ostat), Statis & ss Canada, US & Bureau of th & Census. & \\
\hline
\end{tabular}

\section{The principal factors driving immigration}

10. Knowledge on why some people migrate and what happens when they do remains still fairly thin, despite a growing literature. ${ }^{6}$ Two general influences on the incentive to emigrate are usually distinguished: "push", or supply side factors affecting the interest and willingness to emigrate and "pull", or demand side factors that affect the demand for immigrants in the destination country.

11. On the supply side, relative expected incomes between host and source countries is generally thought to be an important factor influencing the incentive to migrate. ${ }^{7}$ Relative expected income discrepancies can be approximated by the proportion of per capita income in the source countries (where the data are available) relative to the host country. On this measure, using country average statistics and thus ignoring disparities in income distribution within source and host countries, the incentive to move can be quite sharp (Table 5). ${ }^{8}$ In all the major seven countries, except the United Kingdom, the average annual per capita income in 1997 in the source countries is less than half the level of the host country, whereas the

6. The literature on this aspect of migration emphasises the many and complex forces that operate in the host and source countries that bear on the expected benefits and costs of immigrating. See for instance, Borjas (1999a), Faini (1998), Ghatak, Levine and Wheatley Price, 1996 and Massey et.al, 1993.

7. This follows in the tradition of seminal work by Harris and Todaro (1970) on rural urban migration.

8. The coverage of the immigrants included in the calculations for this table varies widely between countries (from 33 to 89 per cent). This reflects both the lack of data on the full decomposition of host country immigrants by source country and the absence of per capita GDP data for former Yugoslavia, Bosnia, Croatia, Iran, Iraq, Somalia and Zaire. As a consequence of the latter, the relative income indicator is biased upwards, especially in countries such as Denmark, Sweden and Switzerland since a relatively large proportion of their migrants are from source countries where GDP data is lacking. A downward bias, however, is also possible if the low coverage of immigrants is related to insufficient information on migrants from other EU countries. 
simple average for all the countries shown in the table is close to two thirds. The United States is fairly unique in that its migratory flows come primarily from countries with very low per capita incomes. ${ }^{9}$ An implication of this dichotomy of per capita incomes between source and host countries is that it is likely that world output and income would rise when immigrants relocate to developed countries. But this is not automatic and depends on the institutional frameworks and policies in the host country which are able to harness the economic potential of new arrivals (see below).

able 4. Employment of foreigners and nationals by industry division ${ }^{a}$

\begin{tabular}{|c|c|c|c|c|c|c|}
\hline \multicolumn{7}{|c|}{$\begin{array}{l}\text { Proportion of total employment of foreigners and nationals } \\
\qquad 1995-1998 \text { average }\end{array}$} \\
\hline & \multicolumn{2}{|c|}{ Agriculture } & \multicolumn{2}{|c|}{ Industry } & \multicolumn{2}{|c|}{ Services } \\
\hline & Foreigners & Nationals & Foreigners & Nationals & Foreigners & Nationals \\
\hline Australia & 2.2 & 5.8 & 26.7 & 20.7 & 71.1 & 73.4 \\
\hline Austria & 1.3 & 7.6 & 42.0 & 29.2 & 56.7 & 63.2 \\
\hline Belgium & 1.1 & 2.7 & 35.9 & 27.1 & 63.0 & 70.3 \\
\hline Canada $^{b}$ & 2.4 & 4.7 & 24.6 & 19.6 & 73.0 & 75.7 \\
\hline Denmark & 4.4 & 3.9 & 22.9 & 26.6 & 72.7 & 69.5 \\
\hline Finland & 3.6 & 7.7 & 23.5 & 27.6 & 72.9 & 64.7 \\
\hline France & 3.2 & 4.8 & 38.2 & 26.0 & 58.7 & 69.3 \\
\hline Germany & 1.4 & 3.1 & 46.3 & 34.1 & 52.3 & 62.8 \\
\hline Greece & 3.9 & 19.9 & 41.3 & 22.5 & 54.7 & 57.6 \\
\hline Ireland & 3.7 & 11.0 & 25.2 & 28.3 & 71.2 & 60.8 \\
\hline Italy & 6.8 & 6.6 & 34.9 & 32.2 & 58.3 & 61.2 \\
\hline Japan $^{C}$ & 0.3 & 5.5 & 64.1 & 61.6 & 35.6 & 33.0 \\
\hline Luxembourg & 1.6 & 3.8 & 28.3 & 20.0 & 70.1 & 76.2 \\
\hline Netherlands & 2.1 & 3.8 & 28.3 & 22.9 & 69.7 & 73.4 \\
\hline Portugal & 1.9 & 12.8 & 38.8 & 32.5 & 59.3 & 54.7 \\
\hline Spain & 7.5 & 8.5 & 20.7 & 30.1 & 71.8 & 61.4 \\
\hline Sweden & 1.5 & 3.3 & 27.2 & 25.7 & 71.3 & 71.0 \\
\hline United Kingdom & 0.7 & 1.9 & 20.2 & 27.4 & 79.1 & 70.7 \\
\hline United States $^{d}$ & 4.2 & 2.4 & 26.2 & 22.6 & 69.5 & 75.0 \\
\hline Total $^{e}$ & 3.3 & 4.3 & 29.2 & 27.4 & 67.5 & 68.4 \\
\hline \multicolumn{7}{|c|}{$\begin{array}{l}\text { a) For each country, the two columns represent breakdowns respectively for foreigners and } \\
\text { nationals (foreign-born and natives for Australia, Canada and the United States). }\end{array}$} \\
\hline \multicolumn{7}{|c|}{ b) 1996.} \\
\hline \multicolumn{7}{|c|}{ c) Foreign employment refers to June 1997. National employment refers to total civilian } \\
\hline \multicolumn{7}{|l|}{$\begin{array}{l}\text { employment for } \\
\text { d) } 1997 \text {. }\end{array}$} \\
\hline \multicolumn{7}{|c|}{$\begin{array}{l}\text { e) For those countries shown in the table, and, where applicable, for the dates noted in the } \\
\text { above footnotes. }\end{array}$} \\
\hline \multicolumn{7}{|c|}{$\begin{array}{l}\text { Sources: OECD Labour Force Statistics, Eurostat, Australian Bureau of Statistics, } \\
\text { Statistics Canada, Japan's Ministry of Justice, US Bureau of Census. }\end{array}$} \\
\hline
\end{tabular}

9. These calculations, however, exclude "non-immigrants". These are people who have the right to remain and work in the United States for up to 6 years, although they often become permanent residents. In recent years the United States has admitted some 600000 "non-immigrants" per year, of which about 80 per cent are skilled workers. It is probable, therefore, that a greater proportion of the "non-immigrants" are from richer countries and earn above average incomes within their own countries, compared with the average immigrant. 
ECO/WKP(2001)10

Table 5. Per capita income in source relative to host countries in current PPP \$, $1997^{a}$

\begin{tabular}{|c|c|c|c|c|}
\hline Host country & $\begin{array}{l}\text { Average number } \\
\text { of immigrants }^{a} \\
\text { (thousands) }^{\text {(thous }}\end{array}$ & $\begin{array}{l}\text { Per cent of total } \\
\text { immigrants included } \\
\text { in calculation }\end{array}$ & $\begin{array}{c}\text { Weighted source } \\
\text { country GDP per } \\
\text { capita in 1997, PPP\$ }\end{array}$ & $\begin{array}{c}\text { Ratio of source } \\
\text { country GDP per } \\
\text { capita to host country } \\
\text { GDP per capita in } \\
1997\end{array}$ \\
\hline Australia & 87.4 & 66.6 & 12265 & 60.7 \\
\hline Belgium & 51.2 & 74.1 & 17688 & 77.7 \\
\hline Canada & 207.3 & 48.6 & 9900 & 44.0 \\
\hline Denmark $^{b}$ & 26.1 & 33.4 & 16679 & 70.4 \\
\hline Finland & 7.8 & 61.2 & 8744 & 43.4 \\
\hline France & 77.5 & 55.3 & 6231 & 28.3 \\
\hline Germany & 679.3 & 49.9 & 10016 & 47.1 \\
\hline Italy ${ }^{c}$ & 111.0 & 67.4 & 8279 & 40.8 \\
\hline Japan & 243.9 & 67.3 & 10387 & 43.2 \\
\hline Netherlands & 75.6 & 43.2 & 15497 & 73.4 \\
\hline Norway & 18.0 & 61.7 & 17565 & 71.8 \\
\hline Sweden & 33.6 & 32.6 & 17835 & 90.1 \\
\hline Switzerland & 77.5 & 50.4 & 19262 & 76.3 \\
\hline United Kingdom ${ }^{b}$ & 219.8 & 89.4 & 14832 & 71.5 \\
\hline United States & 773.8 & 77.8 & 6371 & 22.0 \\
\hline
\end{tabular}

a) Based on immigration flows between 1995-98.

b) Immigration data refer to average 1995-97.

c) Immigration data refer to 1998 only.

Sources: OECD International Migration Database; World Bank Development Indicators, 1999.

12. Relative income discrepancies need not correspond closely with actual migration movements, as these also depend on the immigration policy of the destination country as well as other factors that influence the expected costs and benefits of moving. Moreover, the disparity in relative incomes for a given year is a static measure that does not capture the expected costs and benefits over the life of the migrant, which is considered by some researchers as the more relevant concept when assessing the incentive to migrate (Vishwanath, 1991 and Burda, 1995). Non-economic factors are likewise important. The psychological stress associated with moving to live in another country and the language and cultural differences impinge on the decision to move as well as the choice of destination country. Both the economic and non-economic costs borne by migrants are partially muted by the presence of existing migrant networks in the host country, which therefore provides a strong dynamic force in the choice of destination country, with the source country of recent arrivals influenced, via family reunion programmes, by the settlement patterns of past immigrants (Carrington, Detragiache and Vishwanath, 1996). Moreover, some research (Stark, 1991 and Daveri and Faini, 1999) suggests that international migration acts as a family strategy to diversify sources of income, minimise risks to the household and overcome access barriers to credit markets.

13. On the demand side, the need for migrant workers in many host countries has been stressed. ${ }^{10} \mathrm{~A}$ number of large European countries and the United States have traditionally filled positions in the service sector and in import-competing industries through recourse to foreign labour. This was especially the case

10. See, for instance, Faini (1998). 
between the mid 1950s and the early 1970s when there were widespread labour shortages and countries like Australia, France, Germany and the United Kingdom actively promoted immigration. The importance of this demand side force declined in the aftermath of the first oil shock in 1973. In recent years, there has been a shift in host-country labour demand towards skilled workers and increased emphasis on attracting skilled immigrants in sectors where labour shortages are evident, such as technicians and engineers in the information, communication and technology producing and using industries (see below). A number of OECD countries also allow immigrants to enter temporarily as seasonal workers. These immigrant workers are concentrated in the agricultural sector.

\section{Consequences of immigration and policy issues}

14. All countries, even those where a large proportion of the citizens are themselves descendants of immigrants, manifest tensions between new arrivals and parts of the native population. Such tensions are partly invoked by the perception of unchecked flows of new immigrants as well as overtly anti-immigrant political parties. Opponents of migration fear adverse impacts on the labour market, public finances, social conditions and on the distribution of income. Proponents of migration, on the other hand, note the positive economic role immigrants can play, for instance in terms of addressing specific labour shortages and the problems linked to ageing populations. The debate has also focussed on the role that immigration may play as a mechanism which facilitates economic development in the source countries of immigrants. But the factual basis for these concerns and aspects of international migration are often limited. The following subsections discuss these issues and their implications.

\section{Labour markets and immigration}

\section{Impact on wages and unemployment}

15. Despite no obvious relationship between immigration and unemployment (Figure 3), concerns are often expressed that immigration will lead to higher unemployment and lower wages for the native population. These concerns are especially evident in many European countries, where unemployment rates are higher and the proportion of long-term unemployment is greater than in many non-EU OECD countries. In theory, the labour market impact of immigration depends on how the skills of immigrants compare with those of nationals in the host country. One should expect that the wage income of the migrating factor -- predominantly unskilled labour -- and of others with which it competes will rise in the source country and fall in the destination country (or, if wages in the destination country are inflexible, unemployment will increase), while the wage and income of complementary factors will move in the opposite direction, as production adjusts to the new factor intensities. The distributional impacts are more complex when other factors of production, such as capital, are included in the analysis. ${ }^{11}$

11. See Borjas (1999a) for a formal discussion and extensions to this basic model. 
ECO/WKP(2001)10

Figure 3. Immigration and unemployment rates in OECD countries, $1998{ }^{1}$

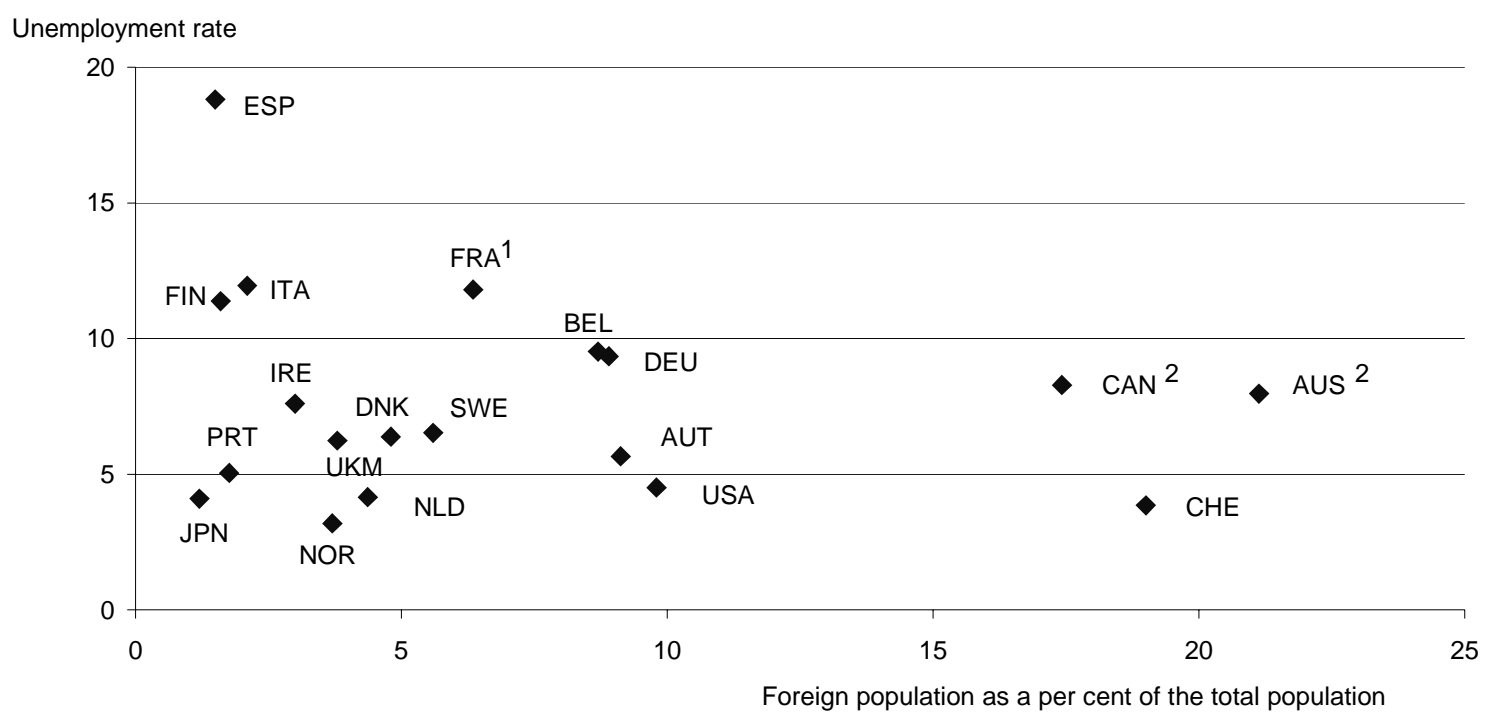

1. Population data refer to 1990 .

2. Population data refer to 1996.

Source: OECD Analytical Data Base; OECD International Migration Database.

16. It is difficult to evaluate the size and nature of these effects, since, apart from differences in skill and educational attainment, they also depend on the volume of immigrants, the different immigration waves, their settlement patterns, as well as the characteristics of migrants, such as sex, age, country of origin and legal status. Moreover, the effects are likely to vary over time as immigrants acquire new skills and experience in the local labour market. And as relative wages change, decisions on human capital investment by the native population are also likely to adjust. Nonetheless, available empirical studies from the United States fail to find that immigration has harmful effects in terms of raising unemployment in the receiving country (Simon, 1989, Borjas, 1990 and 1993 and Friedberg and Hunt, 1995). In Europe the results are less categorical, with a few studies reporting small negative effects of immigration on unemployment (Winkelman and Zimmerman, 1993). Others, however, distinguish between long run and short run impacts and find that while unemployment may initially increase, in the long run the overall rate of unemployment falls permanently (Gross, 1999). These findings may reflect lower labour market flexibility and the slow speed of adjustment in EU economies compared with the United States.

17. Studies which examine the effect of immigration on wages also generally support the predictions of standard theory, although the magnitudes are small. ${ }^{12}$ The size of wage effects from immigration are a function of the wage elasticities of labour demand and native labour supply. In general, the lower the elasticities the larger the wage impact of any given amount of immigration. Most studies suggest that immigration on average has small negative impacts on native wage levels. For the United States, Freidberg and Hunt (1995) report that a 10 per cent increase in the fraction of immigrants in the population -- a large increase -- reduces native wages by at most 1 per cent. When, however, native labour supply is

12. For reviews of the literature see Zimmerman, 1994, Borjas, 1994 and the chapter on the macroeconomic impact of immigration in the 1994 edition of Trends in International Migration. For a detailed summary of the German and Austrian experience, see Winter-Ebmer and Zimmerman, 1998. 
disaggregated by level of skill (Jaeger, 1996), immigration is estimated to have had a larger negative impact on the wages of the low-skilled and a positive impact on those of high-skilled native workers during the 1980s. Similarly, in the European context, a study of German workers found that immigration depressed the wage rate of blue collar workers and increased that of white collar workers in the 1980s (De New and Zimmerman, 1994). In the case of France, Garson et al. (1987) showed that immigration has a very small impact on nationals' wages.

18. Other well known studies of the impact of immigration on the labour market have analysed the nature of adjustment following major one-off immigration shocks. Card (1990) looked at the 1980 Mariel boatlift of Cubans into the Miami area and Hunt (1992) the return of the pied noir from Algeria to France in 1962. These studies show that even major one-off migrations had only small labour market effects, as adjustment was partially facilitated through internal migration of the native-born population and possibly through firm mobility.

19. Although much attention has been paid to the potential adverse effects of immigration on the labour market, migration may in fact confer a number of economic benefits to the host country. First, immigration creates demand for goods and services produced by the host population with favourable consequences for labour demand. Second, immigrants, especially in the EU, tend to serve as a flexible labour reserve and in part compensate for the low geographical or functional mobility of the native born population. ${ }^{13}$ Immigration may hence speed up adjustment to changing conditions and thereby help soften the cost of structural change on the native population. Nonetheless, immigration is not a substitute for flexible markets and potential benefits are only likely to be harnessed if market institutions and policies provide the right framework for both migrants and the native population to look for and find work. Special care is required to avoid undesirable impacts as a result of interactions with other labour and product market policies. For example, minimum wages set too high, or excessively restrictive employment protection legislation could increase the level of structural unemployment and make it especially difficult for new entrants in the labour market to find work.

20. For the economy overall, it is harder still to determine with precision whether immigration induces net benefits or costs. A few studies, however, have attempted to do so and these typically find aggregate net benefits for the native population. Borjas (1999b) for instance reported, based on the US experience, a small net gain, equivalent to 0.1 per cent of GDP or $\$ 10$ billion per annum. The benefits, however, are not necessarily evenly distributed and some groups (e.g. those whose labour is substitutable with immigrants) could lose from immigration. Moreover, the transfers of wealth could be many multiples the size of the net benefits.

\section{Integration of migrants into the labour market}

21. An assessment of the economic impact of immigration depends to a large degree on the economic performance of immigrants themselves and how quickly they adapt to the new environment. Different perspectives on these issues underlie much of the debate on the appropriate level of immigration and the desired characteristics of the immigrant flow. How quickly an immigrant succeeds in integrating into the labour market, for instance, impinges on the debate concerning the size of the fiscal cost of immigration (see below) and the policies, such as language training, that are specifically designed to facilitate the pace of migrant assimilation.

13. See OECD (1999b) for a detailed discussion on geographic labour mobility within the euro zone. 
Figure 4. Foreign-born and native unemployment rates

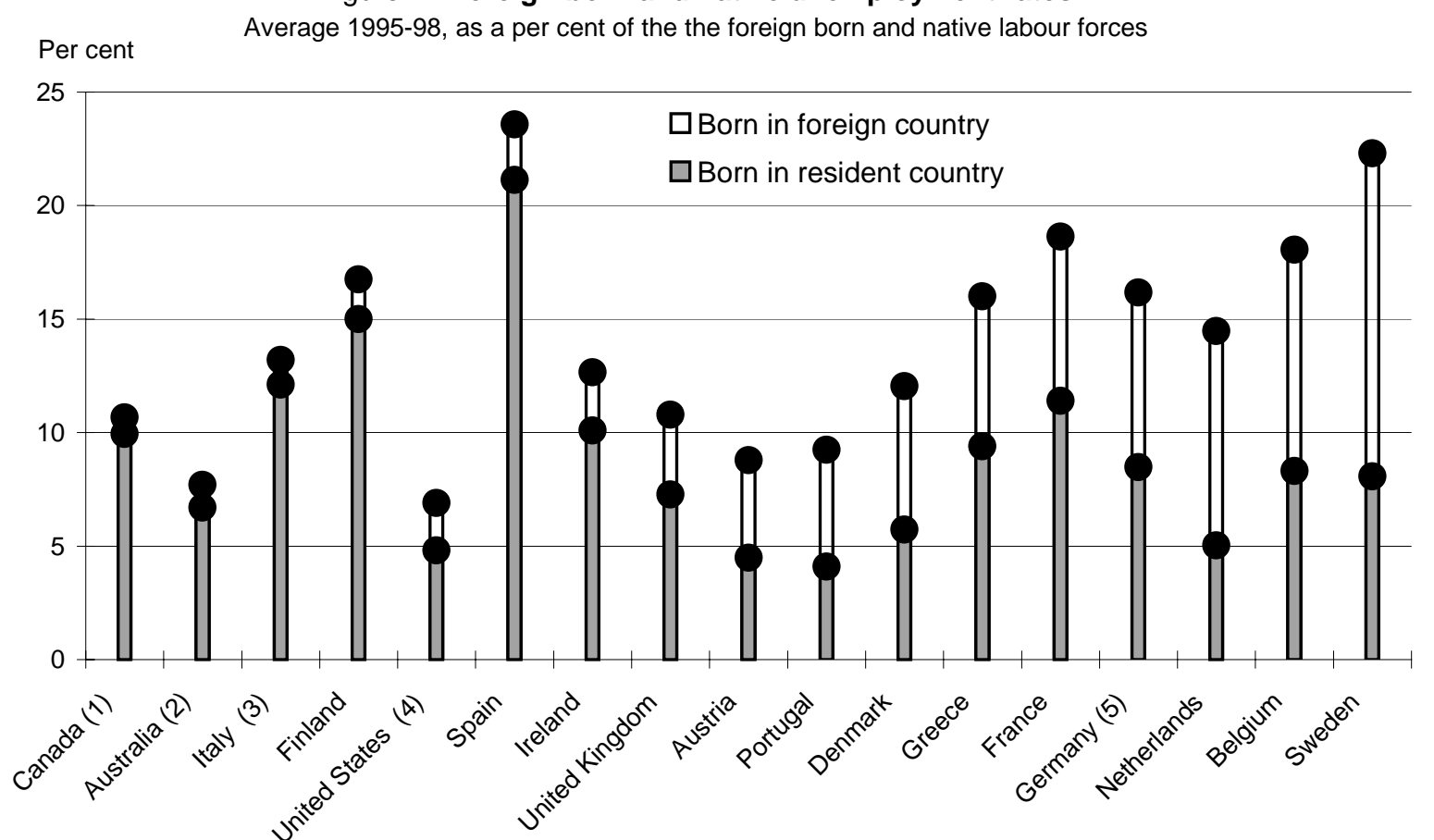

1. Data refer to 1996.

2. Data refer to 1998.

3. Data refer to $1995-97$.

4. Data refer to 1997.

5. Data refer to foreigners and nationals, instead of foreign-born and native.

Source: OECD Labour Force Statistics; OECD International Migration Database.

22. In fact, immigrants on average and especially in EU countries, tend to have a considerably higher rate of unemployment than the native population (Figure 4) and earn less than natives at the time of arrival into the host country. The higher unemployment rate for foreign born workers, however, conceals a wide range, depending to a large extent on the length of time the immigrant has been in the host country. The differences between the unemployment rates of foreign-born and the native-born population decline over time and approaches that for nationals, as immigrants acquire language skills, better understand labour market institutions and improve their qualifications. Moreover, as this process of assimilation matures, wage convergence between immigrants and natives advances (Borjas, 1998 and LaLonde and Topel, 1992). The experience among the immigrant population, however, varies widely depending on the immigrants' level of skill and the time elapsed since arrival (Butcher and DiNardo, 1998). But since the rate of wage convergence is typically low, and given the size of the wage gap at the time of entry, immigrants probably experience a wage disadvantage for most of their working lives (Schoeni, McCarthy and Vernez, 1996). ${ }^{14}$

14. The wage gap in the United States between foreign-born and native-born workers also depends on the age of the immigrant at arrival. Those who migrate at a young age experience earnings paths that do not differ much from natives, since most of their work experience and human capital are obtained in the host country. But those who enter at older ages initially face a large earnings gap which, given more limited economic opportunities, declines only slowly throughout the remainder of their working lives and not rapidly enough to unwind the earnings gap. 
23. The social costs of unemployment among immigrants may well be higher than for the population at large, as it is likely to be concentrated in local ethnic communities. High ethnic unemployment could also heighten tensions with the native population. In a number of OECD countries a relatively high proportion of foreigners tend to live in disadvantaged areas with above average unemployment rates, a larger proportion of lone parent families and a lower educational attainment level compared with the national average (Table 6). On the one hand, this tends to make it more difficult to resolve these problems with policies framed at the national level. And on the other hand, local communities do not have, or receive sufficient, resources from the central government to address the specific problems of deprived areas. The result can be entrenched and concentrated pockets of poverty which are difficult for their residents to exit from (OECD, 1998c).

Table 6. Disparities between disadvantaged areas and the urban average in selected $O E C D^{a}$

\begin{tabular}{lccccccc}
\hline & $\begin{array}{c}\text { Ratio of rates } \\
\text { of unemployment }\end{array}$ & $\begin{array}{c}\text { Population } \\
\text { under 15 }\end{array}$ & Over 65 & $\begin{array}{c}\text { Lone parent } \\
\text { families }\end{array}$ & $\begin{array}{c}\text { Non-national } \\
\text { population }\end{array}$ & $\begin{array}{c}\text { Education } \\
\text { attainment }\end{array}$ & $\begin{array}{c}\text { Rental } \\
\text { housing }\end{array}$ \\
\cline { 2 - 8 } Canada & 1.9 & 0.81 & 0.84 & 1.72 & 1.40 & 0.80 & 1.10 \\
Finland & 1.4 & 0.89 & 0.88 & 1.23 & 1.67 & 0.67 & 2.20 \\
France & 1.9 & 1.27 & 0.81 & 2.35 & 2.11 & 0.52 & $3.8^{b}$ \\
Sweden & 1.4 & 1.10 & 0.63 & 1.55 & 2.71 & $\ldots$. & 1.80 \\
United States & 1.6 & 1.13 & 1.14 & 2.44 & 1.57 & 0.44 & 1.30 \\
\hline
\end{tabular}

a) Data are expressed as a ratio of disadvantaged areas to the urban average.

b) For France, rental housing includes only HLM (habitation loyer modéré) units.

Source: OECD (1998c).

24. The origins of a number of these problems are historical and can be traced back to the era of high immigration flows in the 1960s and early 1970s. Coupled with relatively fast native population growth, the public infrastructure, such as schools, hospitals and low cost housing had difficulty keeping up with the rising demand, resulting in a dilution of these public and social services, often among the least well off. Nonetheless, such problems are not directly associated with immigration per se. Rather, they reflect inadequate financing of public infrastructures and poor social planning and these weaknesses were magnified by the existence of high immigrant inflows.

\section{Immigration and skilled labour shortages}

25. Structural shifts in OECD economies towards more "knowledge" intensive output have raised the demand for skilled labour. In some sectors, such as information technology (IT), the increase has been sizeable and rapid and made it difficult for employers to find suitably qualified workers. For instance, the unemployment rate for IT workers in the United States is currently less than 2 per cent and salaries have increased at a pace above the national rate, both common features for other high skilled workers. This has led to some calls for increased immigration and particularly a re-orientation of migration policies to favour attracting high skilled individuals on a temporary basis.

26. A number of OECD countries have already adapted their legislation in order to facilitate the entry of skilled foreign workers as a partial response to skilled labour shortages. For instance, the Japanese authorities have extended the maximum visa duration for some categories of skilled workers from one to three years. In the United States, caps to temporary immigration have recently been raised and in the same vein, the United Kingdom and France introduced a fast-track work permit system in order to speed up the recruitment of foreign workers by companies experiencing severe skill shortages. Finally, the German government has launched a temporary immigration programme in order to recruit IT specialists. 
27. These initiatives are too recent to show in data on the composition of immigrant arrivals. But given the multiple criteria for entry in host countries it will be difficult to radically shift the orientation of immigration programmes. For example, in countries such as Australia and Canada, which have a tradition of selective immigration and have over recent years shifted their focus more in favour of skilled migrants, this category still only accounted for less than a third of the overall number of entrants in 1998, which is only a small increase compared with earlier in the decade (Table 7).

Table 7. Immigration by eligibility category in selected OECD countries ${ }^{a}$ as a percentage of total

\begin{tabular}{|c|c|c|c|c|c|c|c|c|}
\hline & \multicolumn{2}{|c|}{ Family } & \multicolumn{2}{|c|}{ Skills } & \multicolumn{2}{|c|}{ Refugee } & \multicolumn{2}{|c|}{ Other ${ }^{b}$} \\
\hline & 1993 & 1998 & 1993 & 1998 & 1993 & 1998 & 1993 & 1998 \\
\hline Australia $^{C}$ & 42 & 27 & 29 & 34 & 14 & 11 & 15 & 28 \\
\hline Canada & 65 & 61 & 15 & 23 & 10 & 13 & 10 & 3 \\
\hline Denmark $^{d}$ & 29 & 32 & 12 & 11 & 19 & 15 & 40 & 42 \\
\hline France $^{e}$ & 60 & 69 & 28 & 21 & 12 & 10 & - & - \\
\hline New Zealand & 20 & 42 & 73 & 49 & 5 & 9 & 2 & 1 \\
\hline Slovak Republic & 30 & 30 & 43 & 48 & 1 & 2 & 26 & 20 \\
\hline Sweden & 21 & 43 & - & 1 & 75 & 33 & 4 & 23 \\
\hline Switzerland & 41 & 30 & 26 & 33 & 4 & 3 & 29 & 34 \\
\hline United Kingdom ${ }^{f}$ & 40 & 47 & 41 & 45 & 14 & 5 & 4 & 2 \\
\hline United States ${ }^{g}$ & 53 & 72 & 16 & 12 & 14 & 8 & 17 & 8 \\
\hline
\end{tabular}

a) Refers to permanent settlers or equivalent, unless otherwise noted.

b) The category "other" varies according to country. For Australia, this category includes New Zealanders, who may emigrate to Australia without a visa. In Denmark and Sweden "other" includes European Economic Area nationals and students. For the Slovak Republic, this includes mainly students, and for Switzerland it includes mainly students, rentiers and spouses of Swiss nationals.

c) Fiscal year ending June 30 .

d) Refers to residence permits.

e) Excluding visitors and persons who benefited from the 1997-1998 regularisation programme.

f) Passengers, excluding European Economic Area nationals, admitted to the United Kingdom. The data only include certain categories of migrants: work permit holders, spouses and refugees. g) Fiscal year ending September 30.

Sources: OECD (1999), Trends in International Migration, Australian Department of Immigration and Multicultural Affairs (DIMA), Citizenship and Immigration Canada, New Zealand Immigration Service, U.S. Immigration and Naturalization Service, European Migration Centre (EMZ).

\section{Impacts on general government budgets}

28. Part of the public debate regarding the costs and benefits of immigration has centred on the impact that immigrants have on public finances. The question is often phrased in terms of whether immigration places an additional load on social welfare, education and health systems, which is not compensated by higher tax payments. Whether the net contribution to budgetary positions is positive or negative is not just important from a public finance angle, as it may also be a factor influencing policies which encourage or discourage immigration. This discussion has led some governments to put in place policies, such as waiting periods, which restrict access of new arrivals to some social protection payments, including unemployment benefits.

29. Efforts to compute the net fiscal contribution of immigrants are complicated. The results depend very much on the methodology adopted, the time period concerned, the assumptions about what should be considered and excluded, which public services are regarded as pure public goods, the appropriate discount rate and the demographic unit of analysis (individuals or households). The scope of various studies also 
differs, with most serious attempts to quantify immigration effects on government outlays focussed on welfare spending. This work generally finds that foreign born individuals are less likely to receive public assistance and, when they do, to receive lower levels of such transfers than the native-born population with similar characteristics. ${ }^{15}$ Recent analytical work in the United States (for example, Gustman and Steinmeier, 2000), however, finds the likelihood that an immigrant receives social welfare payments and the average amount vis-à-vis the native born population has increased between the beginning of the 1970s and the late 1990s in line with the reduced human capital and poor English language skills possessed by more recent immigrants, both of which are associated with greater welfare use. Welfare recipient rates among immigrants, however, tend to fall with length of settlement in the host country towards the level for the native-born population (Borjas and Hilton, 1996). These findings are also corroborated by data based on the Australian experience (Birrell and Jupp, 2000).

30. Research results that report an additional net burden are more of an accounting exercise, the analysis is static and often lacks an economic framework. This approach is of limited interest because it mixes together immigrants of different generations and it ignores life-cycle effects on demands for public services and the payment of taxes. Studies which follow immigrants over time have mostly suggested that in net present value terms immigrants and their descendants tend to contribute more in terms of tax revenues than they absorb via higher government outlays, but the orders of magnitude are typically small (for a review see OECD, 1997 edition of Trends in International Migration and OECD, 1997). These findings, however, are sensitive to the composition of new immigrants, particularly their level of educational achievement and age at arrival in the host country. In the United States, typically only those immigrants with at least a high school level of educational achievement or those who arrived before the age of 40 have a positive fiscal impact in net present value terms (OECD, 1997). Moreover, given the concentration of immigrants in a few geographic areas, the budgetary impacts at local levels of government may be important, especially in the years following arrival.

\section{Is increased immigration a solution to ageing OECD populations?}

31. One of the major structural changes facing OECD economies is population ageing. ${ }^{16}$ The proportion of the population of working age will decline, particularly in the years after 2010, when the baby boom generation begins to retire. Moreover, under current United Nation population projections, which are based on low or zero net migration flows, the population of the European Union and Japan are expected to fall between year 2000 and 2050 by 12 and 17 per cent respectively, equivalent overall to some 65 million people. In the United States, the overall population is projected to increase, although the proportion of elderly people rises. The main force behind these trends is demographics. Fertility rates have declined and people are living longer in all OECD countries. These processes have been going on for some time and have now reached quite an advanced stage in EU countries and Japan. The problem is also exacerbated by the trend towards early retirement. ${ }^{17}$ Today, less than half the population aged between 55 and 64 in the OECD are employed, and in a number of countries, the figure is less than a third.

32. Contracting or slower growing populations and labour forces will impact on material living standards and generate added fiscal pressures. OECD estimates suggest that the cumulative effect by mid-century could be to reduce the United States' living standards -- measured by GNP per capita adjusted

15. For an overview, see the special chapter on immigration and social transfers in the 1997 edition of OECD, Trends in International Migration.

16. For more detailed discussion on ageing see OECD (1998b) and Visco (2000a).

17. See Blondal and Scarpetta (1999) for an analysis on the incentives favouring early retirement in OECD countries. 
for terms of trade effects -- by 10 per cent, the European Union's by 18 per cent and Japan's by 23 per cent below the level they might have reached extrapolating current productivity trends with unchanged dependency ratios (the proportion of the population above 65 years of age relative to the population aged 15 to 64 years). ${ }^{18}$ Welfare systems in OECD countries will also come under increasing pressure as public pension payments absorb a growing share of total welfare outlays. Thus, unless other government expenditures are reduced or taxes raised, the government budgetary position will deteriorate.

\section{Table 8. Share of foreign births in total births relative to the share of foreigners in the total population in selected OECD countries, 1980 and $1988^{a}$}

\begin{tabular}{|c|c|c|c|c|}
\hline & \multicolumn{2}{|c|}{$\begin{array}{l}\text { Share of foreign births in total births relative to } \\
\text { the share of foreigners in the total population }\end{array}$} & \multicolumn{2}{|c|}{ Share of foreign births in total birth } \\
\hline & $1980^{b}$ & $1998^{c}$ & $1980^{b}$ & $1998^{c}$ \\
\hline Sweden & 2.1 & 2.2 & 10.2 & 13.0 \\
\hline France & 1.5 & 1.6 & 10.2 & 9.6 \\
\hline Norway & 1.3 & 1.6 & 3.4 & 5.8 \\
\hline Finland & 0.3 & 1.5 & 0.1 & 2.3 \\
\hline Switzerland & 1.1 & 1.2 & 15.3 & 22.1 \\
\hline Canada & 1.0 & 1.0 & 15.6 & 18.0 \\
\hline Japan & 0.7 & 0.9 & 0.6 & 1.0 \\
\hline United Kingdom $^{d}$ & 2.0 & 1.9 & 13.3 & 13.1 \\
\hline Germany & 1.5 & 1.4 & 10.9 & 12.7 \\
\hline Netherlands & 2.0 & 1.4 & 7.5 & 5.7 \\
\hline Luxembourg & 1.4 & 1.3 & 37.1 & 45.0 \\
\hline Belgium $^{e}$ & 1.7 & 0.9 & 15.5 & 8.7 \\
\hline \multicolumn{5}{|c|}{$\begin{array}{l}\text { a) Foreign births are births to mothers with foreign nationality for Finland, France, Norway and Sweden. For Japan, they refer to births } \\
\text { to parents with foreign nationalities. For the United Kingdom, they refer to births to mothers born outside of the United Kingdom }\end{array}$} \\
\hline \multicolumn{5}{|c|}{ For Canada, foreign births refer to births to foreign mothers who have obtained immigrant status. } \\
\hline \multicolumn{5}{|c|}{ b) 1986 for Canada and Sweden, 1987 for Finland, 1989 for Japan, and 1991 for Germany. } \\
\hline \multicolumn{5}{|c|}{ c) 1993 for Sweden, 1996 for France and 1997 for the United Kingdom. } \\
\hline \multicolumn{5}{|c|}{$\begin{array}{l}\text { d) Refers to England and Wales. The share of foreign births to total is shown as a percentage of the population born } \\
\text { abroad to the total population. }\end{array}$} \\
\hline \multicolumn{5}{|c|}{ e) The fall in the number of foreign births is largely explained by changes to nationality laws in 1985 and 1992.} \\
\hline
\end{tabular}

33. One option for dealing with ageing populations, which has been rarely analysed in depth, is to increase and change the population age structure through immigration. Increased immigration would have an immediate impact on the working-age population, assuming the relatively young age structure of net migration to apply also in the future. ${ }^{19}$ In addition, fertility rates among immigrant women are often relatively high which can help boost overall fertility and hence long-term population growth (Table 8). In fact, for the EU as a whole, net migration has been a more important source of population growth over the past decade than through natural increase, with a number of European countries virtually, or entirely reliant on immigration for population growth. In the United States and Japan the relative importance of net migration in overall population growth and therefore economic growth has increased over the same period. Nonetheless, in a number of OECD countries, the age profile of the foreign population is not too different from that of the native population (Figure 5). This suggests that maintenance of past migration trends would not be sufficient to offset ageing populations.

18. These results also depend on conservative assumptions concerning migration. For more details on the model, the underlying assumptions used and the simulated scenarios see Turner et al. (1998).

19. The median age of new immigrants is on average about 30 years, compared with 36 years for the overall OECD population. 
Figure 5. Foreign and national population by age group ${ }^{1}$ 1995-1998 average, as a percent of total population of each group

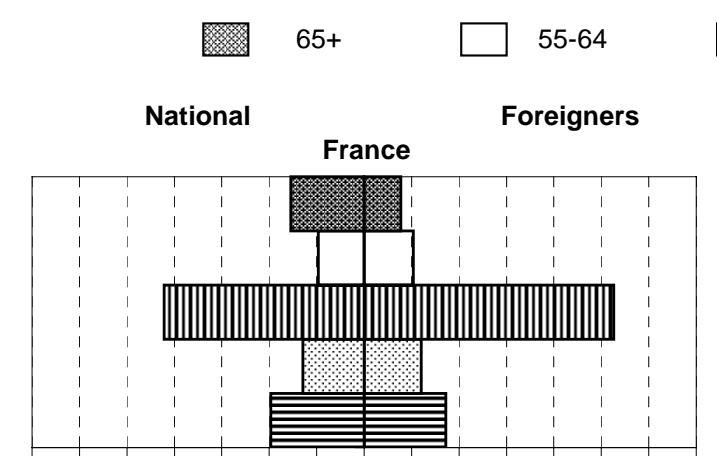

$\begin{array}{lllllllllllllll}-70 & -60 & -50 & -40 & -30 & -20 & -10 & 0 & 10 & 20 & 30 & 40 & 50 & 60 & 70\end{array}$ Per cent

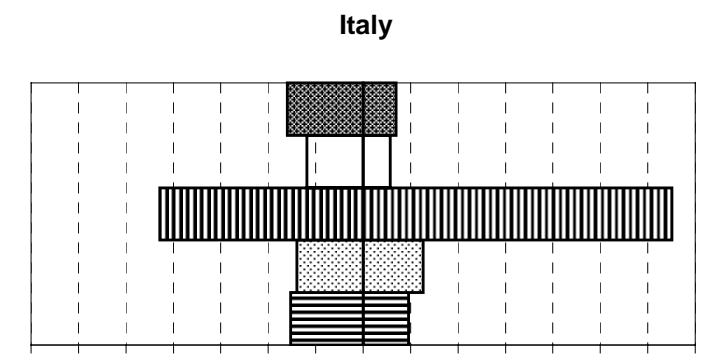

$\begin{array}{lllllllllllllll}-70 & -60 & -50 & -40 & -30 & -20 & -10 & 0 & 10 & 20 & 30 & 40 & 50 & 60 & 70\end{array}$ Per cent

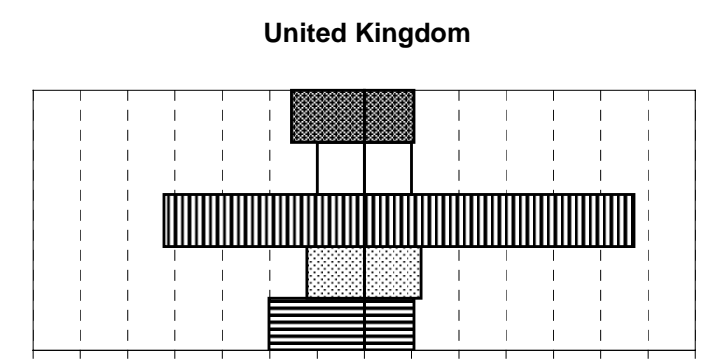

$\begin{array}{lllllllllllllll}-70 & -60 & -50 & -40 & -30 & -20 & -10 & 0 & 10 & 20 & 30 & 40 & 50 & 60 & 70\end{array}$ Per cent

\section{Canada $^{1,2}$}

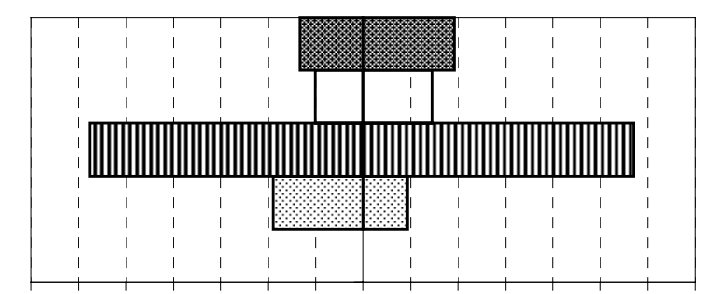

$\begin{array}{lllllllllllllll}-70 & -60 & -50 & -40 & -30 & -20 & -10 & 0 & 10 & 20 & 30 & 40 & 50 & 60 & 70\end{array}$ Per cent
盂耑 $25-54 \quad \begin{array}{llll}15-24 & 0-14\end{array}$

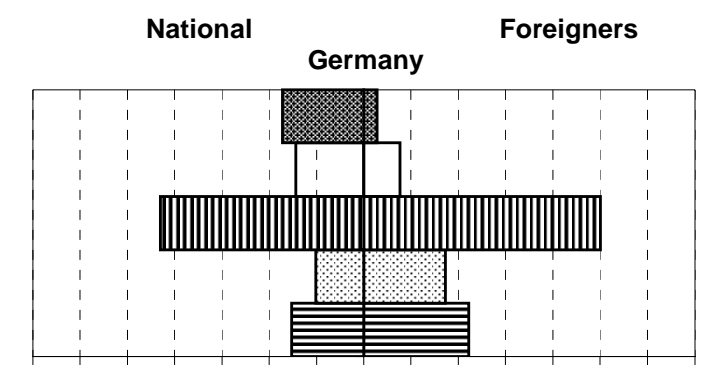

$\begin{array}{ccccccccccccccc}-70 & -60 & -50 & -40 & -30 & -20 & -10 & 0 & 10 & 20 & 30 & 40 & 50 & 60 & 70 \\ \text { Per cent }\end{array}$

Sweden

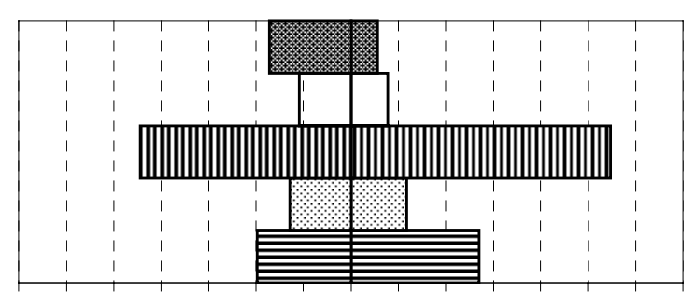

$\begin{array}{lllllllllllllll}-70 & -60 & -50 & -40 & -30 & -20 & -10 & 0 & 10 & 20 & 30 & 40 & 50 & 60 & 70\end{array}$ Per cent

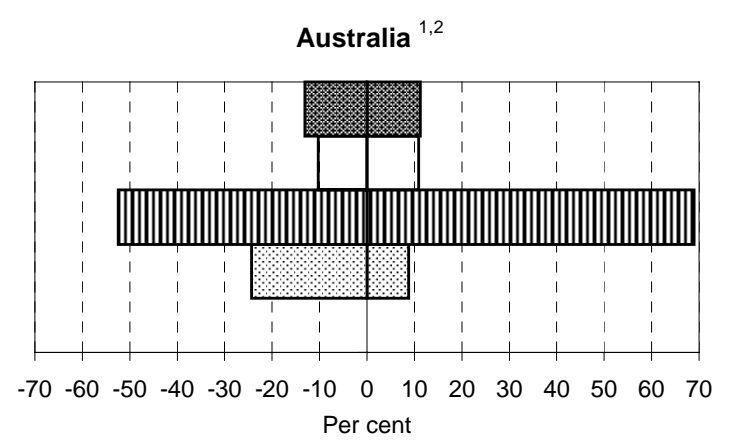

United States $^{1,3}$

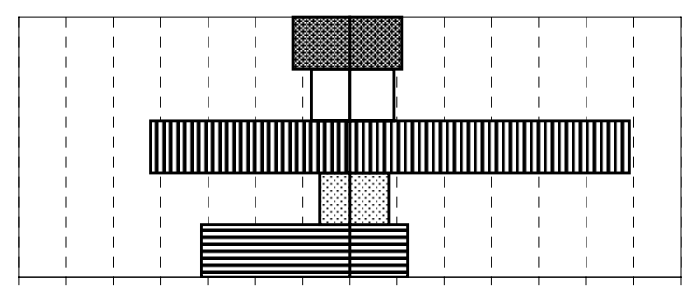

$\begin{array}{lllllllllllllll}-70 & -60 & -50 & -40 & -30 & -20 & -10 & 0 & 10 & 20 & 30 & 40 & 50 & 60 & 70\end{array}$ Per cent

1. Foreign-born and native populations for Australia, Canada and the United States.

2. Population aged 15 and over, for the year 1996.

3. Data refer to 1998.

Source: Eurostat, Australian Bureau of Statistics, Statistics Canada, US Bureau of the Census. 
34. A recent report by the United Nations (United Nations, 2000) has investigated the level of migration required to achieve population objectives in selected countries between 1995 and the year 2050 . Maintaining the size of the population or that of the working-age population (15 to 64 years) at their highest levels reached in the absence of migration after 1995 would imply migration flows for the EU that are not too different than those recorded over the past decade. On average, almost a million net immigrants per year would be required to keep the EU population constant over the period and slightly more than $1 \frac{1 / 2}{2}$ million to maintain a constant working-age population. In contrast, the same scenarios would imply lower net-migration for the United States, compared with recent experience. On the other hand, the level of net migration required in order to maintain the old-age dependency ratio at its 2000 level entails enormous increases in all countries and regions studied, implying very large increases in the overall population (Figure 6).

Figure 6. Immigration and ageing
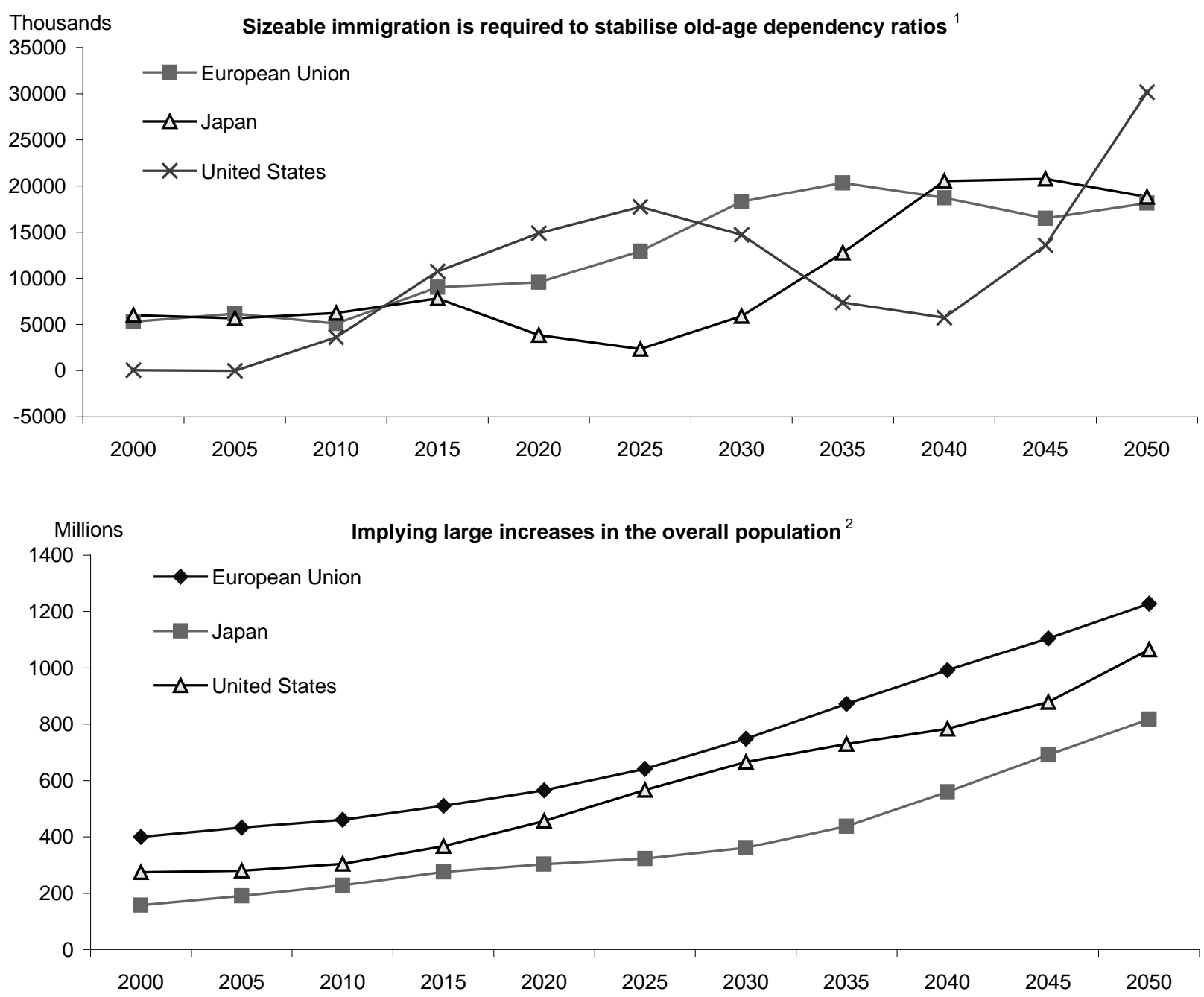

1. Average annual net migration for 5 years ending in the year shown.

2. Total population in the year shown.

Source: United Nations Population Division, Replacement Migration (2000). 
35. Even if these very large increases in migrants could be attracted to countries with ageing populations, immigration policy cannot easily be fine-tuned to reach precise demographic objectives. For instance, while policy may have control over the level of immigration, it has little or no control over emigration and hence net migration is difficult to influence. In addition, the existence of free circulation agreements, the persistence and difficulty of tackling illegal immigration and humanitarian commitments limit and complicate the ability to control the demographic composition of immigration. ${ }^{20}$ Realistically, therefore, while increased immigration can limit the adverse impact on living standards and government budgetary positions due to declining and ageing populations, it cannot on its own solve them. ${ }^{21}$

\section{Development policy issues}

36. Immigration impacts not only on the host country, but in the source country economy as well. One of the major concerns is that the source country will lose its most qualified workers -- the "brain drain" -- and as a result its economic development will suffer. The extent to which this is an issue depends on whether emigrants remain permanently in another country or whether they eventually return to their country of origin. And in many countries the potential for remigration is large. For instance, in other European countries alone, live more than 4 per cent of the Turkish, Portuguese, Greek and former Yugoslav populations. Little, however, is known on the level of, and motivation for remigration, although for the United States it has been estimated that approximately 25 per cent of immigrants eventually return to their country of origin. To the extent that a sizeable fraction of emigrants ultimately return, they may actually serve economic development well, as the experience gained in another country is transferred and applied in the source country. Moreover, remittances from emigrants represent an important source of finance. In Albania, for instance, remittances are one and a half the level of its exports of goods and services and they are equivalent to about 20 per cent of exports in India, Morocco and Greece (Table 9). Overall, workers remittances in the 20 countries shown in the table totalled some $\$ 41$ billion in 1998 , which is close to the net level of official foreign aid from OECD countries.

37. Even if the positive aspects of emigration were outweighed by the loss of skilled workers, it would be hard for policy to respond directly, since democratic governments cannot easily control the outflow of their population. But nor can governments ignore high permanent net emigration. Indeed, it is a signal that something is wrong in the source country economy. Addressing the problem of a "brain drain" is hence connected with policies and the framework conditions that promote economic development and thereby reduce the incentive to migrate in the first instance. This includes investment in physical infrastructure, increased and wider access by the public to education, better public health and the sound operation of legal and regulatory institutions which support the development and proper functioning of markets.

20. Even those countries which have traditionally had selective immigration seem unable to make a large difference to the overall composition of arrivals (Cobb-Clark, 2000, for Australia and Duleep and Regets, 1992, for Canada).

21. For further discussion on the limitations of migration policy as a response to the adverse economic impacts of demographic decline and ageing populations see Tapinos (2000). 
Table 9. Worker remittances in selected emigration countries, 1998

\begin{tabular}{|c|c|c|}
\hline & $\begin{array}{l}\text { Worker remittances, } \\
\text { million US\$ }\end{array}$ & $\begin{array}{l}\text { Workers remittances as } \\
\text { a per cent of exports of } \\
\text { goods and services }\end{array}$ \\
\hline Albania & 452 & 153.5 \\
\hline Jordan & 1543 & 42.5 \\
\hline Bangladesh & 1600 & 27.3 \\
\hline Egypt & 3370 & 26.9 \\
\hline Nicaragua & 200 & 26.3 \\
\hline India & 9453 & 20.7 \\
\hline Morocco & 2011 & 20.2 \\
\hline Jamaica & 659 & 19.5 \\
\hline Greece $^{a}$ & 2816 & 18.9 \\
\hline Dominican Republic & 1326 & 17.7 \\
\hline Sri Lanka & 999 & 17.7 \\
\hline Pakistan $^{a}$ & 1738 & 17.1 \\
\hline Ecuador & 840 & 16.8 \\
\hline Nigeria & 1574 & 16.0 \\
\hline Guatemala & 457 & 13.1 \\
\hline Turkey & 5356 & 9.8 \\
\hline Honduras & 220 & 9.2 \\
\hline Tunisia & 718 & 8.5 \\
\hline Peru & 400 & 5.3 \\
\hline Mexico & 5627 & 4.3 \\
\hline Total of above & 41359 & 12.1 \\
\hline
\end{tabular}

38. While there is no magic code to economic development and possibly a different combination of specific policies may work better in individual country contexts, there is little doubt that increased investment in physical and human capital are universal drivers of economic growth, especially when supported by well functioning markets. In this respect, host countries can also play a role. Often the domestic markets of the source countries of immigrants are small and access to foreign markets in the sectors where they arguably have a comparative advantage is restricted. This is notably the case for agricultural products, textiles and clothing. Thus greater market access to developed country markets and openness to foreign direct investment in emigration countries could enhance work opportunities and thereby lower the incentive to move. ${ }^{22}$ Furthermore, lower trade barriers would weaken the pull factors of migration by lowering output in import-competing sectors that rely heavily on migrant labour. Indeed, regional trade agreements are sometimes advanced as a means to reduce international migration pressures. Foreign aid can also contribute to the development process, especially when it complements domestic policy reforms in the recipient country and provides a conduit for the transmission of technical knowhow. ${ }^{23}$ Initially the negative impact on the incentive to emigrate would be small, but would probably increase over time as the benefits from more open markets and foreign investment take time to materialise. $^{24}$

22. See for instance, Faini and Venturini (1993), Faini, Grether and de Melo (1997), Cogneau, Dumont and Izzo (1998) and Hill and Mendez (1984).

23. See OECD (1999c) for a detailed discussion on the importance of policy coherence.

24. See for instance, OECD, $2000 b$. 


\section{BIBLIOGRAPHY}

AUERBACH, A. and P. OREOPOULOS (1999), "Analysing the fiscal impact of US immigration", American Economic Review, Vol. 89, No. 2.

BIRREL, B. and J. JUPP (2000), Welfare Recipient Patterns Among Migrants, Department of Immigration and Multicultural Affairs, Canberra.

BLONDAL, S. and S. SCARPETTA (1999), "Early retirement in OECD countries: the role of social security systems", OECD Economic Studies, No. 29.

BORJAS, G.J. and L. HILTON (1996), "Immigration and the welfare state: Immigrant participation in means-tested entitlement programmes", Quarterly Journal of Economics, Vol. 111, No. 2.

BORJAS, G.J. and S.J. TREJO (1991), "Immigrant participation in the welfare system”, Industrial and Labour Relations Review, Vol. 44, No. 2.

BORJAS, G.J. (1987), "Self-selection and the earnings of immigrants", The American Economic Review, Vol. 77, No. 4.

BORJAS, G.J. (1990), Friends or Strangers: The Impact of Immigrants on the U.S Economy, Basic Books, New York.

BORJAS, G.J. (1993), "The impact of immigrants on employment opportunities of natives" in OECD, The Changing Course of International Migration, Paris.

BORJAS, G.J. (1994), “The economics of immigration”, Journal of Economic Literature, Vol. 32(4).

BORJAS, G.J. (1995), “The economic benefits from immigration”, Journal of Economic Perspectives, Vol. 9, No. 2.

BORJAS, G.J. (1998), “The economic progress of immigrants", National Bureau of Economic Research, NBER Working Paper, No. 6506.

BORJAS, G.J. (1999a), "The economic analysis of immigration", in Handbook of Labour Economics, Vol. 3A, O. Ashenfelter and D. Card (eds.), North Holland.

BORJAS, G.J. (1999b), “Immigration”, NBER Reporter, Fall.

BURDA ,M. (1995), "Migration and the option value of waiting", CEPR Discussion Paper No.1229.

BUTCHER, K.F and J. DINARDO (1998), "The immigrant and native-born wage distributions: evidence from United States censuses", National Bureau of Economic Research Working Paper 6630.

CARD, D. (1990), "The impact of the Mariel boatlift on the Miami labor market", Industrial and Labour Relations Review, Vol. 43, 2. 
CARILLO, M.F. et al (1999), "Causes and economic effects of migration flows -- an overview", Review of Labour Economics and Industrial Relations, Vol. 13, September.

CARRINGTON, W., E. DETRAGIACHE and T. VISHWANATH (1996), "Migration with endogenous moving costs", The American Economic Review, Vol. 86, No. 4.

COBB-CLARK, D.A. (2000), "Do selection criteria make a difference? Visa category and the labour market status of immigrants to Australia", Economic Record, Vol. 76, No. 232.

COGNEAU, D., J.C. DUMONT and P. IZZO (1998), "Intégration régionale, investissements directs et migrations dans l'espace euro-méditerranéen: enseignements d'un modèle d'équilibre général Calculable", in Migration, libre échange et intégration régionale dans le bassin mediterranéen, OECD, Paris

DAVERI, F. and R. FAINI (1999), "Risk and Migration", in: Labour Markets, Poverty and Development edited by G.B. Navaretti, R. Faini and G. Zanalda, Clarendon Press, Oxford.

DE NEW, J.P. and K.F. ZIMMERMANN (1994), "Native wage impacts of foreign labour: a random effects panel analysis", Journal of Population Economics, Vol. 7, No. 2.

DIMA (1999), Population Flows: Immigration Aspects, Department of Immigration and Multicultural Affairs, Canberra.

DULEEP, H.O. and M.C. REGETS (1992), "Some evidence on the effect of admission criteria on immigrant assimilation", in B.R. Chiswick (ed.), Immigration, Language and Ethnic Issues: Canada and the United States, American Enterprise Institute, Washington, D.C.

DULEEP, H.O. and M.C. REGETS (1997), "Immigrant entry earnings and human capital growth: evidence from the 1960-1980 censuses", Research in Labor Economics, Vol. 16.

FAINI, R. and A. VENTURINI (1993), "Trade, aid and migrations: some basic policy issues", European Economic Review, Vol. 37, No. 2-3.

FAINI, R., J.M. GRETHER and J. DE MELO (1997), "Globalisation and migratory pressures from developing countries: a simulation analysis", CEPR Discussion Paper No. 1660.

FAINI, R. (1998), "European migration policies in American perspective", in B. Eichengreen (ed.), Transatlantic Economic Relations in the Post-Cold War Era, Council on Foreign Relations, Washington D.C.

FREIDBERG, R and J. HUNT (1995), "The impact of immigration on host country wages, employment and growth", Journal of Economic Perspectives, Vol. 9, No. 2.

GARSON, J.P., Y. MOULIER-BOUTANG, R. SILBERMAN and T. MAGNAC (1987), "La substitution des autotcones aux étrangers sur le marché du travail dans la CEE", Commission of the European Communities and GRAMI, Paris.

GARSON, J.P. and C. THOREAU (1999), "Typologie des migrations et analyse de l'intégration" in: P. Dewitte (ed.), Immigration et intégration, l'état des savoirs, éditions de la Découverte, Paris.

GHATAK, S., P. LEVINE and S. WHEATLEY PRICE (1996), "Migration theories and evidence: an assessment", Journal of Economic Surveys, Vol. 10, No. 2. 
GROSS, D.M. (1999), "Three million foreigners, three million unemployed? Immigration and the French labour market", IMF Working Paper, WP/99/124.

GUSTMAN, A. and T. STEINMEIER (2000), Social Security Benefits of immigrants and US Born", in G. Borjas (ed.), Issues in the Economics of Immigration, The University of Chicago Press.

HARRIS, J.R. and M.P. TODARO (1970), "Migration, unemployment and development: a two sector analysis", The American Economic Review, Vol. 60, No. 1.

HARTMAN, R.W. (1994), “Can immigration slow U.S population ageing?”, Journal of Policy Analysis and Management, Vol. 13, No. 4.

HILL, J.K. and J.A. MENDEZ (1984), "The effects of commercial policy on international migration flows: the case of United States and Mexico", Journal of International Economics, Vol. 17, No. 1-2.

HUNT, J. (1992), “The impact of the 1962 repatriates from Algeria on the French labor market", Industrial and Labor Relations Review, Vol. 45, No. 3.

JAEGAR, D.A. (1996), "Skill differences and the effect of immigrants on the wages of natives", U.S Bureau of Labor Statistics Economic Working Paper No. 273.

LALONDE, R.J. and R.H. TOPEL (1992), "The assimilation of immigrants in the U.S. labour market" in G.J. Borjas and R.B. Freeman (eds.), Immigration, Trade and the Labour Market, University of Chicago Press, Chicago.

MASSEY, D.S. et al. (1993), "Theories of international migration: A review and appraisal", Population and Development Review; Vol. 19, No. 3, September.

OECD, Trends in International Migration, Various editions, Paris.

OECD (1991), Migration: the Demographic Aspects, Paris.

OECD (1993), The Changing Course of International Migration, Paris.

OECD (1997), Economic Survey of the United States 1997, Paris.

OECD (1998a), Migration, Free Trade and Regional Integration in North America, Paris.

OECD (1998b), Maintaining Prosperity in an Ageing Society, Paris.

OECD (1998c), Integrating Distressed Urban Areas, Paris.

OECD (1999a), Labour Migration and the Recent Financial Crisis in Asia, Paris.

OECD (1999b), EMU: Facts, Challenges and Policies, Paris.

OECD (1999c), Trade, Investment and Development: Policy Coherence Matters, Paris.

OECD (2000a), OECD Economic Outlook, No. 68, Paris.

OECD (2000b), Globalisation, Migration and Development, Paris. 
OECD (2000c), Combating the Illegal Employment of Foreign Workers, Paris.

RAZIN, A., E. SADKA and P. SWAGEL (1998), "Tax burden and migration: a political economy theory and evidence", NBER Working Paper, No. 6734.

SIMON, J.L (1989), The Economic Consequences of Immigration, Basil Blackwell, Oxford.

SCHOENI, R.F, K.F. McCarthy and G. Vernez (1996), The Mixed Economic progress of Immigrants, Santa Monica, California, The Rand Corporation.

SMITH, J.P. and B. Edmonston (eds.) (1997), The New Americans: Economic, Demographic and Fiscal Effects of Immigration, National Research Council, National Academy press, Washington, D.C.

STARK, O. (1991), The Migration of Labour, Oxford: Basil Blackwell.

TAPINOS, G. (2000), "The role of migration in moderating the effects of population ageing", OECD internal document for the Working Party on Migration.

TURNER, D., C. GIORNO, A. DE SERRES, A. VOURC'H and P. RICHARDSON (1998), "The macroeconomic implications of ageing in a global context", OECD Economics Department Working Paper, No. 193.

UNITED NATIONS (1998), Recommendations on Statistics of International Migration Revision 1, New York.

UNITED NATIONS (2000), Replacement Migration: Is it a Solution to Declining and Ageing Populations?, Population Division, Department of Economics and Social Affairs, New York.

VISCO, I. (2000a), "Welfare systems, ageing and work: an OECD perspective", Banca Nazionale del Lavoro Quarterly Review, Vol. 53, No. 212.

VISCO, I. (2000b), "Immigration, development and the labour market", presentation at the conference: Migration: Scenarios for the $21^{\text {st }}$ century, Rome, 12-14 July.

VISHWANATH, T. (1991), "Information flow, job search and migration", Journal of Development Economics, Vol. 36, No. 2.

WARREN, R. (1997), "Estimates of the unauthorised immigrant population residing in the United States: October 1996", Unpublished Document from the U.S. Immigration and Naturalisation Service, Office of Policy and Planning.

WINKELMAN, R. and K.F. ZIMMERMAN (1993), “Ageing, migration and labour mobility”, in Johnson, P. and K.F Zimmerman (eds.), Labour Markets in an Ageing Europe, Cambridge University Press.

WINTER-EBMER, R. and K.F. ZIMMERMAN (1998), "East-west trade and migration: the AustroGerman case”, Institute for the Study of Labour (IZA) Discussion Paper, No. 2.

ZIMMERMAN, K.F. (1994), "European migration: push and pull”, in Proceedings Volume of the World Bank Annual Conference on Development Economics, supplement to the World Economic Review and the World Bank Research Observer. 
ECO/WKP(2001)10

ZIMMERMAN, K.F. (1995), "Tackling the European migration problem", Journal of Economic Perspectives, Vol. 9, No. 2. 


\section{ECONOMICS DEPARTMENT \\ WORKING PAPERS}

283. Economic Growth: The Role of Policies and Institutions.

Panel Data Evidence from OECD Countries

(January 2001) Andrea Bassanini, Stefano Scarpetta and Philip Hemmings

282. Does Human Capital Matter for Growth in OECD Countries? Evidence from Pooled Mean-Group Estimates (January 2001) Andrea Bassanini and Stefano Scarpetta

281. The Tax System in New Zealand: An Appraisal and Options for Charge (January 2001) Thomas Dalsgaard

280. Contributions of Financial Systems to Growth in OECD Countries (January 2001) Michael Leahy, Sebastian Schich, Gert Wehinger, Florian Pelgrin and Thorsteinn Thorgeirsson

279. House Prices and Economic Activity

(January 2001) Nathalie Girouard and Sveinbjörn Blöndal

278. Encouraging Environmentally Sustainable Growth in the United States (January 2001) Paul O’Brien

277. Encouraging Environmentally Sustainable Growth in Denmark (January 2001) Paul O’Brien and Jens Høj

276. Making Growth more Environmentally Sustainable in Germany (January 2001) Grant Kirkpatrick, Gernot Klepper and Robert Price

275. Central Control of Regional Budgets : Theory with Applications to Russia (January 2001) John M. Litwack

274. A Post-Mortem on Economic Outlook Projections (December 2000) Vassiliki Koutsogeorgopoulou

273. Fixed Cost, Imperfect Competition and Bias in Technology Measurement: Japan and the United States (December 2000) Kiyohiko G. Nishimura and Masato Shirai

272. Entry, Exit, and Aggregate Productivity Growth: Micro Evidence on Korean Manufacturing (December 2000) Chin-Hee Hahn

271. The Tax System in Korea: More Fairness and Less Complexity Required (December 2000) Thomas Dalsgaard

270. A Multi-Gas Assessment of the Kyoto Protocol (October 2000) Jean-Marc Burniaux

269. The Changing Health System in France (October 2000) Yukata Imai, Stéphane Jacobzone and Patrick Lenain

268. Inward Investment and Technical Progress in the UK Manufacturing Sector (October 2000) Florence Hubert and Nigel Pain 


\section{ECO/WKP(2001)10}

267. Aggregate Growth: What have we Learned from Microeconomic Evidence? (October 2000) John Haltiwanger

266. Determinants of Long-term Growth: A Bayesian Averaging of Classical Estimates (BACE) Approach (October 2000) Gernot Doppelhofer, Ronald I. Miller and Xavier Sala-i-Martin

265. The Great Reversals: The Politics of Financial Development in the $20^{\text {th }}$ Century (October 2000) Raghuram G. Rajan and Luigi Zingales

264. Trade and Growth: Still Disagreement about the Relationship (October 2000) Robert Baldwin

263. Growth Effects of Education and Social Capital in the OECD Countries (October) Jonathan Temple

262. Human Capital in Growth Regressions: How Much Difference Does Data Quality Make? (October 2000) Angel de la Fuente and Rafael Doménech

261. Raising the Speed Limit: US Economic Growth in the Information Age (October 2000) Dale W. Jorgenson and Kevin J. Stiroh

260. Summary of an Informal Workshop on the Causes of Economic Growth (October 2000) Jonathan Temple

259. Knowledge, Technology and Economic Growth: Recent Evidence from OECD Countries (October 2000) Andrea Bassanini, Stefano Scarpetta and Ignazio Visco

258. Average Effective Tax Rates on Capital, Labour and Consumption (October 2000) David Carey and Harry Tchilinguirian

257. The Health Care System in Poland (September 2000) Nathalie Girouard and Yutaka Imai

256. Public Expenditure Reform: The Health Care Sector in the United Kingdom (August 2000) Vincent Koen

255. Regulatory Reform in Road Freight and Retail Distribution (August 2000) Olivier Boylaud

254. Regulation, Market Structure and Performance in Air Passenger Transportation (August 2000) Rauf Gonenc and Giuseppe Nicoletti

253. Policy Interdependence during Economic Transition: the Case of Slovakia 1999-2000 (June 2000) Joaquim Oliveira Martins and Tristan Price

252. E-Commerce: Impacts and Policy Challenges (June 2000) Jonathan Coppel

251. The Implementation and the Effects of Regulatory Reform: Past Experience and Current Issues (June 2000) Rauf Gonenc, Maria Maher and Giuseppe Nicoletti

250. The Concept, Policy Use and Measurement of Structural Unemployment: Estimating a Time Varying NAIRU across 21 OECD Countries (June 2000) Pete Richardson, Laurence Boone, Claude Giorno, Mara Meacci, David Rae and David Turner 